\title{
The Responsive Model of Contract Law
}

\author{
Melvin Aron Eisenberg*
}

The principles of contract law can be ranged along various spectra, according to the kinds of variables on which the application of any given principle depends. One such spectrum runs from objectivity to subjectivity. A principle of contract law lies at the objective end of this spectrum if its application depends on a directly observable state of the world, and at the subjective end if its application depends on a mental state. For example, application of the plainmeaning rule of interpretation depends on a determination of observable meanings attached to words by established communities. In contrast, application of the rule that if both parties attach the same meaning to an expression, that meaning prevails, depends on a determination of the parties' mental states. I shall refer to the principles that lie at each end of this spectrum as objective and subjective principles, respectively.

A second spectrum of principles runs from standardization to individualization. A principle of contract law lies at the standardized end of this spectrum if its application depends on an abstract variable that is unrelated to the intentions of the parties or the particular circumstances of the transaction, and at the individualized end if its application depends on situation-specific variables that relate to intentions and circumstances. For example, application of the doctrine that adequacy of consideration will not be reviewed depends on a single variable-the presence of a bargain-that is deliberately designed to screen out all information concerning intentions and circumstances. In contrast, application of the doctrine of unconscionability depends on a number of situation-specific variables that are wholly concerned with that sort of information. I shall refer to the

* Koret Professor of Business Law, University of California, Berkeley. A.B., Columbia, 1956; L.L.B., Harvard 1959.

Earlier versions of this article were presented at the U.S.C. Legal Theory Workshop, the Boalt Hall Faculty Colloquium, and a joint meeting of the AALS Sections on Contracts and Law and Economics. Many valuable comments were made by participants at each of these meetings, and also by friends and colleagues who read part or all of the manuscript independently, including Bob Cooter, Meir Dan-Cohen, Jim Gordley, Tom Jackson, Alan Schwartz, David Slawson, Mike Smith, and Jan Vetter. 
principles that lie at each end of this spectrum as standardized and individualized principles, respectively.

Two polar models of contract law can be constructed on the basis of these two spectra. Under one of these models, which I shall refer to as the will model, contract law is subjective and individualized. Under the second, which I shall refer to as the classical model, contract law is standardized and rigorously objective. The will model was reflected in English cases decided in the late eighteenth and early nineteenth centuries, ${ }^{1}$ but its influence on the common law soon waned. ${ }^{2}$ In contrast, the classical model was central to the teachings of a school of thought, now referred to as classical contract law, ${ }^{3}$ which found its central inspiration in Langdell, Holmes, and Williston, and its central expression in the Restatement (First) of Contracts, and which held virtually absolute sway over contract theory in the late nineteenth and early twentieth centuries. ${ }^{4}$

The adherents of the classical school seldom justified their positions except in axiomatic and deductive terms. However, we can easily imagine the philosophical, psychological, jurisprudential, and pragmatic reasons that would have accounted for the embrace of the classical model by the adherents of the classical school.

Philosophically, the embrace of the classical model seems to have reflected a desire to conform the method of law to the method of science. ${ }^{5}$ By confining its attention to objective phenomena, law, like science, could deal solely with the observable and the knowable. For some, the model may also have reflected a broader program in which a single norm could generate all legal rules: Actors must conform

1. See, e.g., Dickinson v. Dodds, [1876] 2 Ch. D. 463; Adams v. Lindsell, 1 B.\& Ald. 681, 106 Eng. Rep. 250 (K.B. 1818); Cooke v. Oxley, 3 T.R. 653, 100 Eng. Rep. 785 (K.B. 1790); F. Pollock, Principles of Contract 1-6 (1876); Whittier, The Reslatement of Contracts and Mutual Assent, 17 CALIF. L. REv. 441, 441-42 (1929); Williston, Mutual Assent in the Formation of Contracts, 14 ILL. L. REV. 85 (1919).

2. See, e.g., P. Atiyah, The Rise and Fall of Freedom of Contract 407-08 (1979).

3. See, e.g., id. at 681-715.

4. The teachings of the classical school continue to be influential. See Eisenberg, The Principles of Consideration, 67 CORNELL L. REV. 640 (1982).

5. See C. Langdell, A Selection of Cases on the Law of Contracts vi-vii (1871); A. Sutherland, The Law at Harvard 174-75 (1967); Vetter, The Evolution of Holmes: Holmes and Evolution, 72 CALIF. L. REV. 343, 362-65 (1984); (effect of evolutionary theory, scientific history, and pragmatic concept of experimentalism on Holmes's thought); $f f$ Cohen, The Holmes-Cohen Correspondence, 9 HIST. IDEAS 3.14 \& n.27 (1948)(Holmes had once remarked to Felix Cohen that the gap between Holmes's generation and his father's seemed to be the widest of all the intellectual gaps between generations. Cohen asked whether this might be ascribed to the influence of Voltaire. Holmes responded, "Oh no-it was not Voltaire-it was the influence of the scientific way of looking at the world that made the change . . . ."). 
their activity to the conduct one could reasonably expect of the average person. ${ }^{6}$ Today, however, it is clear that law is not a scientific institution whose principles and theories are descriptive and predictive, but a purposive institution whose principles and theories are normative and prescriptive. It is also clear that law generally, and contract law specifically, have too many rooms to unlock with one key.

Psychologically, the assumption underlying the embrace of the classical model seems to have been that everyone knows, or can fairly be taken to know, the law. For some, the model may also have reflected a behavioristic theory that assumes either that subjective states of mind are nonexistent or that because they are unobservable they are unknowable, so that we must accept conventional objective signs as tokens of the interior states to which the signs normally correspond. ${ }^{7}$ If everyone indeed had perfect information concerning the rules of contract law, standardized and rigorously objective rules might be desirable wealth-maximizing devices: On the one hand, they might reduce the transaction costs of judicial administration; on the other, it might be argued, they would raise no problem of fairness and little problem of efficiency, since parties could contract around any rules that did not conform to normal expectations. In the real world, however, the empirical evidence- consisting of the common experience of those trained in the law-strongly suggests that private actors, taken as a class, have little or no significant knowledge of contract law. A contract rule founded on the assumption that they do have such knowledge is therefore likely to bring contracting parties to grief. Even where contracting parties do know contract law, the transaction costs of contracting around standardized rules that do not reflect normal expectations would almost certainly exceed any expected savings in judicial administration, since many more contracts are written than litigated. It is also clear that a behavioristic approach provides a completely unsuitable basis for contract law: Contract is a social institution before it is a legal institution, and the rules of contract law must respond to the social institution, not to autonomous legal conventions. Because the social institution is designed to facilitate the advancement of individual objectives, contract law must be designed to deal with acts that often cannot even be properly described unless intentions are taken into account.

Jurisprudentially, the embrace of the classical model seems to

6. See, e.g., O.W. Holmes, The Common Law 49-59 (1881).

7. Holmes avoided this pitfall. See id. at 37-38. 
have reflected an attitude that legal institutions should arrive at contract law rules through the deductive elaboration of a closely knit axiomatic system, rather than through analysis based on fairness and policy. As Holmes once put it, "I sometimes tell students that the law schools pursue an inspirational combined with a logical method, that is, the postulates are taken for granted upon authority without inquiry into their worth, and then logic is used as the only tool to develop the results." 8

Finally, despite its formal de-emphasis of policy, the classical school's philosophical, psychological, and jurisprudential assumptions seem to have reflected an extremely strong premium on certainty. As contract law approaches the limits of objectivity and standardization, so too does it approach "that lawyer's paradise where . . . if the writer has been careful, a lawyer, having a document referred to him, may sit in his chair, inspect the text, and answer all questions without raising his eyes." Today, however, it is clear that the value of certainty may be purchased at too high a cost of injustice, and that even during the height of its reign, classical contract law failed to achieve the certainty at which it aimed. ${ }^{10}$

The last thirty to forty years have brought a wholesome reaction against the rigidities of the classical school. Unfortunately, the apparent force of the classical school's closely knit axiomatic system is so strong that even some of its most vigorous critics have implicitly accepted its premise that a general theory of contract law must be standardized and rigorously objective. This premise is, for example, at the core of both Gilmore's The Death of Contract and Friedman's Contract Law in America, as vividly exemplified in Gilmore's reliance on a central passage from Friedman:

Basically, then, the "pure" law of contract is an area of what we can call abstract relationships. Pure contract doctrine is blind to details of subject matter and person. It does not ask who buys and who sells, and what is bought and sold. . . . Contract law is an abstractionwhat is left in the law relating to agreements when all particularities of person and subject-matter are removed.

Thus Professor Friedman. Although we shall depart from his

8. O.W. Holmes, Law in Science and Science in Law, in Collected Legal Papers 238 (1920).

9. J. Thayer, A Preliminary Treatise on Evidence at the Common Law 428-29 (1898).

10. See, e.g., note 23 infra and accompanying text. 
analysis at some points, we may retain as central ideas the concept of the general law of contract as a residual category . . . highly abstract, . . . a theoretical construct, which, having little or nothing to do with the real world, would not-or could not-change as the real world changed. ${ }^{11}$

The reaction against standardization and rigorous objectivity was proper. These elements, however, were not necessary features of contract theory, but simply an artifact of the classical model. The task now is to reconceptualize contract law so that it consists of a body of principles that are both intellectually coherent and sufficiently opentextured to encompass the complex and evolving realities of contract as a social institution. ${ }^{12}$

The essentials of the model upon which such a reconceptualization should be founded can be stated briefly:

The principles of contract law should be based on considerations of fairness, as determined principally by conventional morality, and of policy, as determined principally by efficiency and administrability. Accordingly, the extent to which the principles that govern any given issue should be individualized or standardized, or subjective or objective, should depend on a functional analysis of the relevant issue in terms of fairness and policy. Because a major goal of contract law is to facilitate the realization of individual objectives, and because individualization will rarely conflict with fairness and only occasionally with policy, it is to be expected that most contract law principles will be individualized. Because principles whose application depends on a party's state of mind would often conflict with fairness and policy, it is to be expected that many and perhaps most contract law principles will be objective as well. However, subjective principles should be employed where they serve both fairness and policy, and where they do not, it is to be expected, given the goal of facilitating the realization of individual objectives, that the principles employed will often or

11. G. Gilmore, The Death of Contract 6-7 (1974) (quoting L. Friedman, ConTRACT LAW IN AMERICA 20-24 (1965)); see also Friedman \& Macaulay, Contract Law and Contract Teaching: Past, Present and Future, 1967 WIS. L. REv. 805, 812 (fundamental concepts of contract law "too general and abstract to regulate current, socially significant business problems").

12. This is the fourth in a series of articles attempting such a reconceptualization. See Eisenberg, Donative Promises, 47 U. CHI. L. REv. 1 (1979); Eisenberg, The Bargain Principle and Its Limils, 95 HARV. L. REv. 741 (1982); Eisenberg, supra note 4. 
even typically depend on objective variables that provide a reliable surrogate for state of mind.

I shall call this the responsive model of contract law. ${ }^{13}$ I believe this model fairly conceptualizes most areas of modern contract law, but it would be tedious to explore that thesis. Instead, this article will focus on the application of the model to the law of consideration (Part I), interpretation (Part II), and remedies (Part III). Part I, much of Part II, and a portion of Part III will be directed to showing that most or all of the principles in these areas, once conceptualized by the classical model, may now be explained by the responsive model instead. The balance of Parts I-III will show why and how other principles in these areas should move in the same direction. The application of the responsive model to some other contract law topics will be considered briefly in the conclusion. I will show throughout that the responsive model does not entail an abandonment of general principles in favor of decisions based on the equities of each case, but rather a shift from particularized rules to general principles.

\section{Consideration}

The first great issue in contract law is what kinds of promises the law should enforce-an issue usually subsumed under the heading of consideration. An analysis based on fairness and policy suggests that the law should enforce several different categories of promise, in varying degrees. For example, the law should normally enforce bargain promises to the full extent of the promise, donative promises to the extent of any reliance, and promises based on a benefit conferred that gave rise to a moral obligation to the extent of the benefit. ${ }^{14} \mathrm{~A}$ basic axiom of the classical school, however, was that to constitute consideration a promise or performance must be bargained for-the so-called bargain theory of consideration. Under this theory, the classical school rejected the enforceability of nonbargain promises as a matter of principle, although several very narrow categories of nonbargain promises (such as promises under seal and promises to pay a debt discharged by bankruptcy or barred by the statute of limitations) were deemed enforceable on strictly precedential grounds.

Ironically, as the bargain theory of consideration was actually elaborated by the classical school, it could be satisfied even though

13. For a description of a generalized concept of responsive law, see $P$. NONET \& $P$. Selznick, LaW and Societry in Transition-Toward Responsive LaW 73-113 (1978).

14. See Eisenberg, supra note 4. 
no bargain had been made. Under the doctrine of nominal consideration, embraced by Holmes and the Restatement (First), the form of a bargain would suffice to make a promise enforceable. ${ }^{15}$ Holmes expressed his view in two well-known aphorisms:

Consideration is as much a form as a seal ${ }^{16}$ and

$[\mathrm{I}] \mathrm{t}$ is the essence of a consideration, that, by the terms of the agreement, it is given and accepted as the motive or inducement of the promise. Conversely, the promise must be made and accepted as the conventional motive or inducement for furnishing the consider-

15. The case law generally rejected the doctrine of nominal consideration, except in the option and surety contexts, where the setting is commercial and reliance is likely. See In re Green, 45 F.2d 428 (S.D.N.Y. 1930); Schnell v. Nell, 17 Ind. 29 (1861); Fischer v. Union Trust Co., 138 Mich. 612, 101 N.W. 852 (1904); Motzkin Bros. Cleaners \& Dyers, Inc. v. Dime, 82 N.Y.S.2d 279 (N.Y. Sup. Ct. 1948); T.P. Shepard \& Co. v. Rhodes, 7 R.I. 470 (1863); 42 A.L.I. Proc. 251 (1965) ("I reviewed the criticism [of illustration 1 to $\$ 84$ of the Restatement (First)] and tried to find authority on the subject, and the fact is that I was unable to find any authority whatever to support this illustration. I was able to find quite a lot of authority exactly contrary to the illustration . ....) (remarks of Prof. Braucher); Note, Restatement of Contracts (Second) -A Rejection of Nominal Consideration?', I VAL. U. L. REV. 102 (1966); Note, The Peppercom Theory and the Restatement of Contracts, 10 WM. \& MARY L. REv. 201 (1968). But see Thomas v. Thomas, [1842] 2 Q.B. 850, 114 Eng. Rep. 330. The Restatement now gives special treatment to nominal consideration in option and surety contexts. See Restatement (SECOND) OF CONTRACTs $\S \S 87,88$ (1979).

Williston's position on the problem of nominal consideration, as reflected in his treatise, was not as clear as the position embodied in Restalement (First), of which he was the Reporter:

Sometimes a consideration of one dollar or other small sum is paid or alleged to have been paid in return for a promise to give or do something of considerable value. There seems no reason to depart in such a case from the general rule that adequacy of consideration will not be regarded, though an inquiry whether the dollar was really bargained for as the consideration, will always be pertinent; for where a promise of value is stated to have been made for a small money consideration, there is often reason to doubt whether a bargain to exchange the sum mentioned for the promise was really intended by the parties. The only exception to the legal sufficiency of inadequate consideration is where the consideration is of the same nature as the thing promised and is equal or smaller in amount. The reason for this exception is that in such a case it is impossible for the law to indulge in the presumption of equivalence between the consideration and the promise. . . . So a bargain stated to be "in consideration of one dollar by each to the other paid" does not support a contract even though it be assumed that the sum of one dollar was actually paid by each party to the other.

$1 \mathrm{~S}$. Williston, The Law OF ConTRacts 240-41 (1920)(footnotes omitted).

The statement that "an inquiry whether the dollar was really bargained for as the consideration, will always be pertinent" seems inconsistent with Illustration 1 to $\S 84$. However, the balance of the passage suggests that Williston regarded transactions involving an exchange of two sums of money as sui generis, because the lack of equivalence is obvious. The treatise would then presumably be squared with the Restatement on the ground that the Restatement Illustration does not involve an exchange of sums, and the courts should not review anything except the exchange of sums.

16. Krell v. Codman, 154 Mass. 454, 456, 28 N.E. 578, 578 (1891). 
ation. The root of the whole matter is the relation of reciprocal conventional inducement, each for the other, between consideration and promise. ${ }^{17}$

By the term "reciprocal inducement," Holmes meant bargain. By the term "conventional," Holmes apparently meant a formal expression whose meaning and significance is artificially determined, like a bidding convention in the game of bridge. ${ }^{18}$ Thus, if the parties deliberately adopted the convention (form) of a bargain, the law would enforce their promises as though they had deliberately adopted the convention (form) of the seal. Illustration 1 to section 84 of Restatement (First) expressed the same idea:

A wishes to make a binding promise to his son $B$ to convey to $B$ Blackacre, which is worth $\$ 5000$. Being advised that a gratuitous promise is not binding, A writes to $B$ an offer to sell Blackacre for $\$ 1$. B accepts. B's promise to pay $\$ 1$ is sufficient consideration.

The doctrine of nominal consideration provides a critical insight into both the classical school and its centerpiece, the bargain theory of consideration. The shortcomings of that theory are striking. For example, it unsoundly renders unenforceable such important types of promise as firm offers and readjustments of going bargains, and unfairly precludes compensation for reasonable reliance on a nonbargain promise. ${ }^{19}$ In light of such drawbacks, the question arises why the classical school adopted the bargain theory despite a pool of cases that would have supported a much more expansive concept of

17. O.W. Holmes, supra note 6, at 293-94. See also Holmes' opinion in Wisconsin \& Mich. Ry. v. Powers, 191 U.S. 379, 386 (1903):

In the case at bar, of course the building and operating of the railroad was a sufficient detriment or change of position to constitute a consideration if the other elements were present. But the other elements are that the promise and the detriment are the conventional inducements each for the other. No matter what the actual motive may have been, by the express or implied terms of the supposed contract, the promise and the consideration must purport to be the motive each for the other, in whole or at least in part. It is not enough that the promise induces the detriment or that the detriment induces the promise, if the other half is wanting.

18. See OXFORD ENGuish Dictionary 386-87 (1933). The term "convention" can also be used to mean "agreement," but it seems unlikely that this was Holmes' meaning. Since all agreements are reciprocal, if by "convention" Holmes meant "agreement," the second aphorism would read virtually the same way with or without the term "convention." Furthermore, reading convention to mean agreement would make the two aphorisms inconsistent, because whether an agreement has been reached is not a question of form.

Another possible meaning of convention is "contract," in the sense of a legally enforceable agreement. However, this interpretation would be subject both to the objections entailed by reading the term to mean agreement, and to the additional objection that the first aphorism would then be circular because the very issue raised by consideration is whether a contract has been formed.

19. See Eisenberg, supra note 4 , at 641-42. 
enforceability. ${ }^{20}$

One possible explanation is that the classical school associated contract with the commercial sphere of life. This explanation, however, fails to account for the acceptance of nominal consideration, which would render enforceable even noncommercial promises like that in Illustration 1 to section 84 .

A second possible explanation is that the classical school associated contract with reciprocity. This explanation also fails to account for the acceptance of nominal consideration, which would be most useful in the context of nonreciprocal transactions like that in Illustration 1 .

A third possible explanation, which accounts for both the bargain theory and the doctrine of nominal consideration, is that only by coupling the theory with the doctrine could the classical school provide an account of consideration that satisfied the classical model's requirements of standardization and rigorous objectivity. The enforcement of promises on the basis of a benefit conferred that gave rise to a moral obligation fails to satisfy this model, because it involves individualization. The enforcement of donative promises on the basis of reliance fails to satisfy this model, because it involves not only individualization but subjectivity. Taken alone, even the bargain theory fails to satisfy the classical model. ${ }^{21} \mathrm{~A}$ bargain is an exchange in which each party views the performance that he undertakes as the price of the performance undertaken by the other. Whether each party to an exchange regards his performance as the price of the other's-whether, that is, an exchange is a bargainultimately depends on subjective intent. Similarly, only subjective intent separates transactions that are bargains in both form and substance from transactions that are bargains only in form. By coupling the bargain theory with the doctrine of nominal consideration, however, the classical school was able to fashion a theory of consideration that met the test of the classical model. Under this coupling, an objective and abstract variable-the presence or absence of the bargain form-would control the issue of enforceability, and the enforceable would be separated from the unenforceable by a token that doubled

20. See, e.g., Devecmon v. Shaw, 69 Md. 199, 14 A. 464 (1888) (reliance makes a donative promise enforceable); Edson v. Poppe, 24 S.D. 466, 124 N.W. 441 (1910) (promise to pay for a benefit conferred without request held enforceable); Bagge v. Slade, [1614] 3 Bulst. 162, 81 Eng. Rep. 137 (Coke, C.J.) (part payment of a debt is consideration for promise to discharge the balance).

21. See Eisenberg, The Bargain Principle and Its Limits, supra note 12, at 742. 
as a bright line. ${ }^{22}$

In the event, however, it became clear that the certainty aimed at by the bargain theory was purchased at too high a cost of injustice and inefficiency. The concept that only bargain promises were enforceable was unsupported by any convincing arguments of fairness or policy, and often barred enforcement where enforcement would promote fairness, as in the case of reliance, or efficiency, as in the case of firm offers. Furthermore, the bargain theory never really achieved the desired certainty: Even at its height, courts often manipulated the bargain theory to serve the ends of justice. ${ }^{23}$

During the last fifty years, therefore, the law of consideration has moved from the narrow standardization and rigorous objectivity of the bargain theory to a rich menu of individualized principles that reflect both objective and subjective elements. For example, the old rule that a donative promise is not enforceable even if it is reliedupon ${ }^{24}$ has been replaced by the individualized principle that action in reliance makes a promise enforceable if the action is induced by the promise (a subjective test) and is reasonable (an objective test). ${ }^{25}$ The old rule that forbearance to assert a claim is consideration only if the claim is reasonable ${ }^{26}$ has been replaced by the modern rule that forbearance to assert a claim is consideration if the claim is either honestly held (subjective) or doubtful in fact (objective). ${ }^{27}$ The old rule that a past benefit conferred does not make a promise enforcea$b^{28}$ is being replaced by the individualized principle that such a promise is enforceable to the extent of the benefit conferred when the past benefit gave rise to a moral obligation. ${ }^{29}$ Perhaps most striking,

22. Given this underpinning, it is understandable that despite its embrace of the bargain theory of consideration, the classical school never tried to overthrow the older but also standardized and objective rules that a promise is enforceable if made under seal, or if based on an obligation barred by the statute of limitations or discharged in bankruptcy. Similarly, it is not surprising that the classical school never sanctioned a doctrine of unconscionability, and instead embraced norms like the legal-duty rule and the illusory-promise doctrine, which could be made, within limits, to serve the end of fairness while preserving a facade of standardization and objectivism.

23. See, e.g., Gurfein v. Werbelovsky, 97 Conn. 703, 118 A. 32 (1922) (manipulation of illusory-promise doctrine); Siegel v. Spear \& Co., 234 N.Y. 479, 138 N.E. 414 (1923) (manipulation of the definition of a bargain); Schwartzreich v. Bauman-Basch, Inc., 231 N.Y. 196, 131 N.E. 887 (1921) (manipulation of legal-duty rule).

24. See, e.g., Kirksey v. Kirksey, 8 Ala. 131 (1845).

25. See, e.g., Restatement (Second) of Contracts $\$ 90$ (1979).

26. Springstead v. Nees, 125 App. Div. 230, 109 N.Y.S. 148 (1908).

27. See, e.g., Restatement (SeCond) OF Contracts $\$ 74(1)$ (1979).

28. See, e.g., Harrington v. Taylor, 225 N.C. 690 , 36 S.E.2d 227 (1945).

29. Restatement (SECOND) OF CONTRACTS $§ 86$ (1979). 
Restatement (Second), in two Illustrations to a section on the requirement of exchange, has reversed the position of Restatement (First) on nominal consideration, and adopted a test that requires a bargain in fact rather than in form.

4. A desires to make a binding promise to give $\$ 1000$ to his son B. Being advised that a gratuitous promise is not binding, A writes out and signs a false recital that B has sold him a car for $\$ 1000$ and a promise to pay that amount. There is no consideration for A's promise.

5. A desires to make a binding promise to give $\$ 1000$ to his son B. Being advised that a gratuitous promise is not binding, $A$ offers to buy from $B$ for $\$ 1000$ a book worth less than $\$ 1$. B accepts the offer knowing that the purchase of the book is a mere pretense. There is no consideration for A's promise to pay $\$ 1000 .^{30}$

In short, if attention is focused on the actual principles of enforceability, the modern law of consideration reflects the responsive model, in which individualized and even subjective elements are given scope, not the standardized and rigorously objective classical model.

\section{INTERPRETATION ${ }^{31}$}

In parallel to the bargain theory of consideration, the classical school adopted as a central axiom the objective theory of interpretation. As that theory was put in Woburn National Bank v. Woods,

A contract involves what is called a meeting of the minds of the parties. But this does not mean that they must have arrived at a common mental state touching the matter in hand. The standard by which their conduct is judged and their rights are limited is not internal, but external. In the absence of fraud or incapacity, the question is: what did the party say and do? "The making of a contract does not depend upon the state of the parties' minds; it depends on their overt acts."32

30. Id. $\S 71$. Comment b, illustrations $4-5$.

31. Issues of interpretation may arise in determining whether a bargain has been concluded or in determining the meaning of language in an admitted bargain. For simplicity in exposition, Part II will analyze only the former problem, but in most if not all cases a parallel analysis would apply to the latter.

32. 77 N.H. 172, 175, 89 A. 491, 492 (1914). See also Learned Hand's famous passage in Hotchkiss v. National City Bank, 200 F. 287, 293 (S.D.N.Y. 1911), affd, 201 F. 664 (2d Cir. 1912), affd, 231 U.S. 50 (1913):

A contract has, strictly speaking, nothing to do with the personal, or individual, intent of the parties. A contract is an obligation attached by the mere force of law to certain acts of the parties, usually words, which ordinarily accompany and represent a known intent. If, however, it were proved by twenty bishops that either party, when he used the words, intended something else than the usual meaning 
The objective theory of interpretation did not in itself require standardization. At least as regards written contracts, however, standardization was achieved by the companion plain-meaning rule, which prohibited resort to evidence outside the contract where the meaning of an expression was "plain and unambiguous" on its face. ${ }^{33}$ As in the area of consideration, therefore, classical contract law attempted to address the problems of interpretation with one or two objective and standardized substantive principles "taken for granted ... without inquiry into their worth." ${ }^{34}$ In contrast, I will show in Part II that the problems of interpretation can be adequately dealt with only by a set of principles that rest on functional analyses of fault and administrability, that are individualized, that involve subjective as well as objective elements, and that address remedy as well as substance.

The principles of the classical school often seem based on a series of implicit exemplary cases. For example, the principle that courts will not review the adequacy of consideration seems based on the implicit exemplary case of strangers transacting in a perfectly competitive market. ${ }^{35}$ In the area of interpretation, the classical school's implicit exemplary case seems to be one in which two transacting merchants who are strangers attach different meanings to the same expression, that is, to an objective manifestation consisting of words, acts, or both, and one meaning is reasonable while the other is not. Take the following hypothetical:

Case I. $A$ makes an offer to $B$, a stranger, and $B$ responds by addressing an expression to $A$. Both parties are merchants. $B$ does not intend his expression as an acceptance, but a reasonable person would interpret it as an acceptance, as $B$ should know, and $A$ gives it such an interpretation. $B$ does not perform, and $A$ sues for breach of contract.

Given this exemplary case, the objective theory of interpretation is supported by a principle and a policy. The principle is liability for fault. An addressor is at fault-is negligent-if he uses an expression

which the law imposes upon them, he would still be held, unless there were some mutual mistake, or something else of the sort. Of course, if it appear by other words, or acts, of the parties, that they attribute a peculiar meaning to such words as they use in the contract, that meaning will prevail, but only by virtue of the other words, and not because of their unexpressed intent.

33. See J. Calamari \& J. Perillo, The Law of Contracts 117 (2d ed. 1977).

34. O.W. HOLMES, supra note 8, at 238.

35. See Eisenberg, The Bargain Principle and Its Limits, supra note 12, at 746-48. 
that he should realize would lead a reasonable person in the addressee's position to believe that the addressor intends a given meaning when he does not. The policy, known as security of transactions, is that in order to promote commerce, contracts should be reliable. This policy would be undermined if the addressor's unreasonable and undisclosed meaning could prevail in situations like Case I. A party who has made a losing contract could then try to avoid liability by claiming such a meaning. The claim would be hard for the addressee to refute, since it would relate to the addressor's own state of mind. A potential for such claims might therefore make contracts unduly insecure. ${ }^{36}$

36. Even in the exemplary case, a distinction might be drawn between (1) whether subjective or objective interpretation governs, and (2) whether, even if objective interpretation governs, evidence of subjective interpretation is admissible. In Kabil Dev. Corp. v. Mignot, 279 Or. 151, 566 P.2d 505 (1977), Kabil claimed that a conversation at a meeting between its vice president, Munroe, and Mignot's agent, constituted an oral contract for helicopter work by Mignot. Mignot disputed this claim. Over Mignot's objection, the court allowed Munroe to testify that after the meeting "I felt that we were obligated to [Mignot], and equally I felt they were obligated to us." Id. at 154, 566 P.2d at 507. On appeal, the Oregon Supreme Court held that admission of this evidence was proper:

This court has stated, in cases involving the interpretation of the parties' agreement, that it "subscribes to the objective theory of contracts." . . .

But accepting the test of manifested assent regardless of subjective intent does not dispose of the present question. It need not follow that the test also compels that a party be kept from testifying as to whether he thought at the time of the events that he was in fact entering into an agreement. Here the witness was permitted to testify that he did, indeed, act in the belief that he was making a contract. More often, no doubt, the subjective testimony seeks to deny or vary the objectively manifested agreement asserted by the opposing party, which is what concerns the objective theorists. . . .

Usually, however, probative testimony is admissible unless some rule compels its exclusion, and it is difficult to deny that a person's own view of his position in a negotiation can bear on his behavior as perceived by other parties. That perception is, of course, the crux of the objective theory. . . . When the dispute concerns an unwritten agreement, the conclusion that the parties' manifested mutual assent must be constructed from evidence of their negotiations or other past conduct. It must be constructed from their "communications and overt acts," not their "undisclosed intents and ideas," . . . but in face-to-face negotiations, words are not everything, and a fact-finder might well believe that what a party thought he was doing would show in what he did. Thus it was not error to permit Munroe to testify to his own sense of the state of negotiations, as long as the jury was not misled into treating this testimony, in its context, as something more than evidence bearing on the behavior and the perceptions of the parties to the negotiation.

We are not persuaded that the jury was so misled in this case. The jury was instructed that its conclusion depended upon an "objective test", under which "the manifestation of a party's intention, rather than the actual or real intention, is controlling"; that the essential agreement "is not determined by the secret intentions, which may be totally different." The instruction as a whole might have been stated in different ways, but as given it met the point of the present objection. 
The difficult question in such cases is not liability, but damages. Since the addressor is held liable as a principled matter only because he has used language carelessly, the issue is whether he should be liable in tort for the addressee's costs, or in contract for the addressee's expectation. The argument for tort was put strongly by Whittier in 1929:

As an original proposition the wisdom of the [doctrine that a party who did not actually assent to a contract may be held to it if he carelessly led the other party reasonably to think there was assent] may well be doubted. It would have simplified our law of contracts if actual meeting of the minds mutually communicated had remained essential. The liability for carelessly misleading the other party into the reasonable belief that there was assent might well have been held to be in tort . . . . Under the present law the non-consenting party is liable on the contract itself if careless. The chief unfortunate result of this state of the law is that he is bound to the contract though the other party is notified of the mistake before the latter has changed his position or suffered any damage. To hold one for a merely careless use of language which causes no damage whatever to the party to whom the language is addressed is certainly inconsistent with principles generally applied. If $\mathrm{D}$ drives down Michigan Avenue, Chicago, in a careless manner but no one is hurt, can any of those who might have been hurt sue $D ?^{37}$

Strictly as a matter of principle, Whittier's analysis has considerable force (although he assumes the absence of any injury, while in fact the addressor has negligently created and violated a legitimate expectation). The rule is emerging that a party who makes a contract under a unilateral mistake will ordinarily be liable only for reliance damages. ${ }^{38}$ In support of Whittier's conclusion, the law might treat $B$ 's behavior in Case $I$ as a variant of unilateral mistake. ${ }^{39}$

Against that approach, however, is a constraint of administrability. Conventional unilateral-mistake cases typically involve some type of computational error that is corroborated by persuasive objective evidence (such as a bid sheet that omits an item or shows a mistake in addition), and is discovered very soon after contract formation. ${ }^{40}$ In contrast, a party who bases a defense on an unreasonable subjective interpretation normally has no objective evidence to support the claim, and typically the dispute arises well after contract

Id. at 156-58, 566 P.2d at 508-09 (footnotes omitted).

37. Whittier, supra note 1 , at 441-42.

38. See Restatement (Second) of Contracts $§ 153$ (1979).

39. I owe this observation to David Slawson.

40. See, e.g., Elsinore Union Elementary School Dist. v. Kastorff, 54 Cal. 2d 380, 353 P.2d 713, 6 Cal. Rptr. 1 (1960). 
formation (and often well after performance has begun). Reliance then becomes extremely difficult to measure, particularly since it is likely to consist of forgone opportunities or abstinence from considering alternative courses of action. If a defendant, by convincing the factfinder that his subjective intent varied from the reasonable meaning of his expression, could both avoid expectation damages and put the burden on the plaintiff to establish the existence and extent of any costs, contracts might be rendered unduly insecure and private planning might be unduly jeopardized.

While a rigorously objective theory of interpretation may seem justified on the simple facts of the exemplary case, as further elements are added it becomes clear that individualization is necessary in all cases, and subjective elements must be recognized in some. Let us begin with a case in which the parties are not strangers:

Case II. $A$ addresses an expression to $B$, which he does not intend as an offer. A reasonable person who did not have knowledge about $A$ 's characteristics would interpret his expression as an offer, but a reasonable person who did have knowledge about $A$ 's characteristics would not. $B$ has knowledge of $A$ 's characteristics (as $A$ knows), but interprets $A$ 's expression as an offer, and addresses an acceptance to $A$. $A$ does not perform, and $B$ sues for breach of contract.

Under the plain-meaning rule, $A$ might have been bound if his expression was "plain and unambiguous" on its face. That rule is now justifiably in general disrepute. ${ }^{41} B$, not $A$, is at fault, and $A$ should not be liable. The principle for determining the reasonableness of an interpretation should not be standardized, so that it merely reflects what a featureless reasonable addressee would have thought, but instead should be individualized, so that it takes into account what a reasonable person standing in the addressee's shoes-having the addressee's knowledge- would have thought.

It is a nice question whether framing the issue in this way makes the result turn on the addressee's state of mind. While a rule whose application depends on a party's knowledge is individualized, it need not be subjective. For legal purposes, knowledge encompasses two basic categories: facts about the world ( $A$ is a practical joker, has no money, and works as a taxi driver), and inferences that are to be drawn from those facts (an offer by $A$ to invest $\$ 2$ million to help begin a recombinant DNA business ought not to be taken at face

41. See J. Calamari \& J. Perillo, supra note 33 , at 117-18. 
value). Inferences clearly may be either subjective or objective. If an addressee actually drew an inference, he knew subjectively. However, the law may treat an addressee as if he drew an inference, because objectively (reasonably) he should have. So when we say that a person "should have known" or "had reason to know," we usually mean that a reasonable person would have drawn a certain inference. Similarly, although less obviously, we may also view knowledge as subjective or objective. A person may be said to have had knowledge of a fact either because he actually knew it, in the sense that he had it in mind at the relevant time, or because he should have had it in mind on the basis of information to which he had been exposed and that he was capable of understanding. So if $B$ has heard on many occasions that $A$ is a practical joker, the law may treat $B$ as having had knowledge of that fact even if he has forgotten it. Accordingly, Case $I I$ does not necessarily entail a determination of $B$ 's state of mind.

Cases $I$ and $I I$ show that objective elements have an important place in the law of interpretation. So, however, do subjective elements:

Case III. $A$ addresses an expression to $B$ that a reasonable person standing in $B$ 's shoes would interpret as an offer. $B$ so interprets it, and responds by addressing an expression to $A$ that $B$ intends as an acceptance of $A$ 's terms. A reasonable person would interpret $B$ 's expression as an acceptance of $A$ 's terms, and $A$ so interprets it. Unknown to either $A$ or $B$, however, $A$ 's expression can be used with equal reason to refer to two materially different states of the world, $S 1$ and $S 2$. $A$ uses the expression intending $S /$. $B$ interprets the expression to mean $S 2$. $A$ causes $S I$ to occur, but $\mathrm{B}$ refuses to perform on the ground that $S 2$ did not occur. As a result, $A$ and $B$ each incur an out-of-pocket loss, but $A$ 's out-of-pocket loss exceeds $B$ 's.

Case III is derived, of course, from Raffles $v$. Wichelhaus, the famous Peerless case. ${ }^{42}$ There Seller agreed to sell to Buyer 125 bales of Surat cotton to arrive at Liverpool "ex [ship] Peerless from Bombay." There were, however, two ships Peerless that sailed from Bombay, one in October and one in December. Seller meant the December Peerless, and shipped Surat cotton on her. Buyer meant the October

42. 2 H. \& C. 906 , 159 Eng. Rep. 375 (Ex. 1864). 
Peerless, and refused to accept the cotton. ${ }^{43}$ Seller sued for breach of contract. The court held for Buyer on the ground that there was no "consensus ad idem," so that no contract was formed.

To preserve his philosophical program, Holmes struggled to show that the result in the Peerless case could be explained by objective theory. "The true ground of the decision was not that each party meant a different thing from the other . . . but that each said a different thing. The plaintiff offered one thing, the defendant expressed his assent to another." 44 But if both parties subjectively meant the December Peerless, Buyer should have been deemed in breach; and Seller should have been deemed in breach if both the parties subjectively meant the October Peerless. Why not? Holmes had it precisely backward; the result in Peerless is correct, not because the parties said different things, but because they meant different things. Where the parties subjectively attach materially different but equally reasonable meanings to their expressions, the governing rule should be that neither is liable for the other's expectation damages. ${ }^{45}$ This rule does not conflict with the principle of fault, because either both parties are fault-free or both are equally at fault. Nor does it significantly impair the security of transactions, because its application rests on the existence of two meanings of an expression that are equally reasonable under all the circumstances-a condition that is objective, relatively unusual, and difficult to prove.

Again, remedy is the really difficult issue. In Case III, both $A$ and $B$ incurred out-of-pocket losses, but $A$ 's loss exceeded $B$ 's. ${ }^{46}$ The question how to allocate out-of-pocket losses in such cases is much more difficult than the question whether expectation damages should be awarded. It seems to be commonly assumed that in this kind of case any loss should rest where it happens to fall, because no contract is formed, but there is little explicit discussion of this issue in the cases. The probability is high, in situations like Case III, that both parties are at fault - that each had equal reason to know the relevant

43. The facts in the text are as stated in Buyer's answer, to which Seller demurred.

44. O.W. HOLMES, supra note 6 , at 309 .

45. Professor Young has argued that the Peerless rule should apply to expressions in which ambiguity is accidental and surprising, which he calls "equivocation," but not to expressions that are normally used in a "fluctuating way" so that the existence of more than one meaning is not surprising, which he calls "vagueness." Young, Equivocation in the Making of Agreements, 64 Colum. L. REv. 619, 626-28 (1964). The question, however, is whether the two parties gave different but equally reasonable meanings to the same expression. If they did, it should not matter whether each incorrectly thought there was only one meaning, or each correctly thought there was a range of meanings.

46. One or both of the parties may have had such a loss in Peerless, but none was alleged. 
expression was ambiguous. For example, a reasonable merchant might very well have realized that more than one ship could be named Peerless, and that more than one Peerless could be leaving from Bombay. Since in such a case any out-of-pocket loss incurred by either party results from the equal fault of both, there is no good reason why only one party should bear it. ${ }^{47}$ Rather, the rule should be that where each party is equally at fault, out-of-pocket losses should be split evenly.

The relevance of subjective elements extends beyond cases like Peerless, as the following hypothetical shows:

Case $I V$. $A$ makes an offer to $B$, and $B$ responds with an expression addressed to $A$. $B$ does not intend his expression as an acceptance. A reasonable person with $A$ 's knowledge would interpret $B$ 's expression as an acceptance, but $A$ does not so interpret it. $B$ does not perform, and $A$ sues for breach of contract, falsely claiming that he interpreted $B$ 's expression as an acceptance.

Case IV differs from Case III in that $B$ 's expression cannot be used with equal reason to refer to two materially different states of the world. On a strict objectivist view, $B$ would be liable. ${ }^{48}$ However, when both parties have the same subjective interpretation, as in Case $I V$, that interpretation should be determinative. $B$ may have been at fault, but the fault produced no injury, since the expression he used $\operatorname{did}$ not create in $A$ an expectation that a contract was formed. This result would be unlikely to undermine the security of transactions. Unlike Case $I$, where $B$ seeks to avoid liability by establishing his own state of mind, in Case IV $B$ will avoid liability only if he can shoulder the difficult burden of proving $A$ 's state of mind.

47. See Schmidt, Model, Intention, Faull: Three Canons for Interpretation of Contracts, 4 Scandanavian STud. L. 177, 206 (1960); of. Young, Half Measures, 81 Colum. L. Rev. 19 (1981) (examining sections in Restalement (Second) that limit recovery "as justice requires").

48. It is unclear how Restatement (First) would have treated this case. In the absence of an integration, $\S 233$ provided for an objective standard, subject to certain exceptions. One of these exceptions was that:

where a party manifests his intention ambiguously and neither party knows or has reason to know that the other party may give a different meaning to the manifestation, it is given the meaning in favor of each party that he intended it should bear; the same rule is applicable where both parties know or have reason to know of such uncertainty or ambiguity.

The problem is that the term "ambiguous" is itself ambiguous. If an expression is ambiguous whenever it can possibly bear more than one meaning, $\$ 233$ would have applied a subjective standard to transactions like that in Case IV. If, however, an expression is ambiguous only if it has more than one equally reasonable meaning, as in Case III, an objective standard would apply. It seems likely that Restalement (First) contemplated the latter approach. 
The rule that a mutually held subjective interpretation is determinative even if it is objectively unreasonable is well-supported by authority. For example, in Embry v. Hargadine, McKittrick Dry Goods Co., ${ }^{49}$ Embry had a one-year, written employment contract to work for Hargadine, McKittrick that terminated on December 15. He had tried several times to renew the contract, but had been put off. On December 23 he told McKittrick, the company president, that since his written employment had lapsed eight days before, and there were only a few days until January 1 in which to seek employment with other firms, if McKittrick did not give him a contract for another year he would quit then and there. McKittrick asked Embry how he was getting along in his department, and Embry responded that he was very busy getting salesmen out for the height of the season. McKittrick then said, "Go ahead, you're all right. Get your men out, and don't let that worry you." Embry "took McKittrick at his word" and worked until February 15, when he was notified his services would be discontinued on March $1 .^{50}$

The trial court instructed the jury that it should conclude a contract was formed on December 23 if it found that "both parties thereby intended and did contract with each other for [a renewal of Embry's] employment for one year from and including December 23, 1903." 51 The jury returned a verdict for Hargadine, McKittrick. The Missouri Court of Appeals reversed, on the ground that the instruction erroneously implied that McKittrick's subjective intent was determinative even if it did not correspond to the reasonable meaning of his expression. The appeals court made clear, however, that the reasonable meaning of McKittrick's expression was determinative only if Embry's subjective understanding coincided with that meaning.

[D]id what was said constitute a contract of re-employment on the previous terms irrespective of the intention or purpose of McKittrick?

. . In Smith v. Hughes, L.R. 6 Q.B. 597, 607, it was said:

"If, whatever a man's real intention may be, he so conducts himself that a reasonable man would believe that he was assenting to the terms proposed by the other party, and that other party upon that

49. 127 Mo. App. 383, 105 S.W. 777 (1907).

50. Id. at 385, 105 S.W. at 777. The facts in the text are as stated in Embry's testimony. McKittrick gave a somewhat different version of the facts, but the analysis on appeal was based on the legal implications that would follow from Embry's version.

51. Id. at 386,105 S.W. at 778 . 
belief enters into the contract with him, the man thus conducting himself would be equally bound as if he intended to agree to the other party's terms."

... [W]e hold that, though McKittrick may not have intended to employ Embry by what transpired between them according to the latter's testimony, yet if what McKittrick said would have been taken by a reasonable man to be an employment, and Embry so understood it, it constituted a valid contract of employment for the ensuing year. ${ }^{52}$

Restatement (Second) of Contracts reaches a comparable result: In fact, it stands the position of the classical school on its head by giving primacy to mutually held subjective intent. Under section 201, if the parties have attached the same meaning to a promise, that meaning controls. Objective interpretation becomes determinative only if the parties had different subjective meanings, in which case the expression is to be interpreted according to the meaning of one party if he "had no reason to know of any different meaning attached by the other, and the other had reason to know of the meaning attached by the first party."53

A final problem in this area brings out an ambiguity in the objective approach to interpretation and completes the link between substantive and remedial issues:

Case $V$. $A$ makes an offer to $B . B$ responds by addressing an expression to $A$. $B$ does not intend his expression as an acceptance, but $A$ so interprets it. $B$ 's interpretation is reasonable, but $A$ 's interpretation is more reasonable. $B$ does not perform, and $A$ sues for breach of contract.

The objective approach to interpretation tacitly assumes that the world of words has a binary structure, in which an interpretation is either reasonable or unreasonable; that all reasonable interpretations are equally reasonable; and that all unreasonable interpretations are

52. Id. at 387-89, 105 S.W. at 779 (emphasis added); see also Stevens v. G.L. Rugo \& Sons, 115 F. Supp. 61, 62 (D. Mass. 1952), vacated on other grounds, 209 F.2d 135 (1st Cir. 1953); Berke Moore Co. v. Phoenix Bridge Co., 98 N.H. 261, 98 A.2d 150 (1953); 1 A. CoRBIN, CONTRACTS $\S 106$ (1964); 3 id. $§ 538$ (1960).

53. Restatement (SECOND) OF ConTRacts $§ 201$ (2) (1979). The same result follows if one party "did not know of any different meaning attached by the other, and the other knew the meaning attached by" him. Id.

Section 201 of Reslatement (Second) concerns interpretation rather than contract formation. However, at least in the range of cases under consideration, the same canons should apply. In any event, $\S 20$ of Reslatement (Second), which deals with contract formation, takes essentially the same position as section 201, although with somewhat less clarity. 
equally unreasonable. ${ }^{54}$ The real world of words, however, is continuous, not binary. In ordinary usage, we often characterize one interpretation as "better" or "more reasonable" than another-as in Case $V$-and this usage corresponds with the reality of ambiguity.

Assuming this is so, the question is whether in situations like Case $V$ the remedy should be binary, so that the less reasonable party is liable for the other's full expectation damages, or continuous, so that damages are proportioned according to the parties' relative fault. ${ }^{55}$ Like the emerging tort rule of comparative negligence, a proportioned solution would more closely fit the equities of the individual case. Administrative considerations, however, weigh against that approach here. Such a solution might conduce to lazy judicial decisionmaking in which any asserted interpretation would be given some weight, thereby reducing the reliability of contracts. A proportioned solution would also raise the troublesome questions whether the less reasonable party should be entitled to damages if his proportioned loss exceeded that of the more reasonable party; whether a plausible although unreasonable interpretation should be given weight; and if not, how to draw the line between an interpretation that is less reasonable and an interpretation that is unreasonable. Unlike Case III, where the fault of the parties is equal, in Case $V$ one party has acted less reasonably than the other, and it seems appropriate to impose full liability for that relatively unreasonable conduct.

\section{REMEDIES}

The central principle of contract remedies is that the injured party's expectation should be protected by placing him in as good a position as he would have been in had the contract been performed. ${ }^{56}$ This principle, which I shall call the expectation principle, can normally be justified on both fairness and efficiency grounds. Assume that $A$ and $B$ have made a contract that $B$ has breached. If $A$ has performed, protecting his expectation usually amounts to no more than making $B$ pay the price he and $A$ agreed upon. Since we cannot know whether $A$ would have rendered the performance to $B$ for any lesser price, awarding anything less than expectation dam-

54. See, e.g., id. $\$ 20(2)(b)$ : "The manifestations of the parties are operative in accordance with the meaning attached to them by one of the parties if that party has no reason to know of any different meaning attached by the other, and the other has reason to know the meaning attached by the first party."

55. See Schmidt, supra note 47, at 206.

56. See, e.g., Restatement (SECOND) OF ConTracts $\S 344$ (a) (1979). 
ages would unfairly transform $A$ from a voluntary to an involuntary actor, because had $A$ known in advance that the price would be reduced, he might not have contracted and performed. Even if a contract is executory, fairness normally requires that the promisee be compensated for at least the cost he incurred in relying on the contract. In many types of transactions, expectation damages are approximately equal to the cost of reliance, but much easier to measure.

As a matter of efficiency, the contract price normally represents the most efficient price, in the economist's sense of that term. Determining the price of a commodity by the interaction of buyers and sellers will normally move the commodity to its highest-valued useas expressed by the amounts competing buyers are willing to payand will best allocate the factors necessary for the commodity's production. Furthermore, a contract made for forward delivery at a fixed price is frequently intended to allocate the risk of price changes. Efficiency normally requires effectuating this allocation, and expectation damages do just that.

Moreover, parties typically contract for forward delivery in order to plan their future conduct reliably. The extent to which private actors will engage in credit transactions (that is, bargains involving exchanges over time), and make plans on the basis of those transactions, depends partly on the probability that bargain promises will be kept. Efficiency normally requires that such planning be facilitated. By awarding expectation damages, the law makes breach unprofitable in the normal case, and allows the parties to plan as if the contract will be performed. In contrast, failure to enforce bargain promises to their full extent might subvert efficiency by diminishing the willingness of private actors to enter into and plan on the basis of contracts.

I have discussed these reasons and their limits elsewhere. ${ }^{57}$ For now, suffice it to say that the expectation principle is appropriate for the great run of bargain contracts. On its face, this principle is both individualized and subjective, since placing a contracting party where he would have been had the contract been performed seems to require the law to take into account not only the party's individual circumstances but also his subjective valuation of the other party's performance. Traditionally, however, contract remedy rules have tended to be both standardized and objective. I will show in Part III,

57. See Eisenberg, The Bargain Principle and its Limits, supra note 12, at 788-98. 
first, that while administrative obstacles would impede direct measurement of an injured party's subjective valuation, in most cases the party's actual expectation can be vindicated with remedy rules that are objective but individualized; and, second, that modern contract law has taken exactly this direction.

Contract remedy rules fall into two general classes. Some, which I shall call primary remedy rules, govern specific types of transactions, such as contracts for the sale of goods. Others, which I shall call secondary remedy rules, cut across all types of transactions-for example, the rule excluding damages that are not reasonably foreseeable. The major factors that determine the content of primary remedy rules include the class of commodity involved (goods or services), the position of the injured party (buyer or seller), the nature of the injured party (consumer or merchant), and the structure of the market. For the sake of brevity, I will discuss only primary remedy rules governing contracts for the sale of goods and services. However, the primary rules concerning these types of contracts can for the most part be extended to contracts involving other transactions, and several secondary remedy rules will be considered in the conclusion.

\section{A. Contracts for the Sale of Goods}

I shall begin with contracts for the sale of goods. Section 1 considers the general rules governing breach by the seller; section 2 considers the general rules governing breach by the buyer; and section 3 considers a special problem of individualization in which the analyses for buyer and seller are virtually identical.

\section{Breach by the seller.}

Homogeneous goods. If a seller breaches a contract for the sale of goods, the expectation principle might seem to entitle the buyer either to a decree of specific performance or to a judgment for damages measured by the difference between the contract price and the value the buyer subjectively places on the goods. If, however, the contracted-for goods are homogeneous and readily available on the market, the buyer's subjective expectation can be fully protected without resort to these remedies, by using an objective but individualized measure of damages.

Prior to the Uniform Commercial Code, contract law measured a buyer's damages by the difference between the contract price of the goods in question and the market price of such goods at the time of 
delivery. ${ }^{58}$ This is essentially a standardized remedy, partly because it turns on transactions between buyers and sellers as a class, and partly because in the real world there is never a single market price, but only a spread of prices. In effect, the market-price damages remedy reflects the implicit exemplary case of a sale of homogeneous goods in a perfectly competitive market.

The Code retains a market-price measure in section 2-713, but it also introduces an individualized measure of a buyer's damages. Under Section 2-712, a buyer 'may 'cover' by making in good faith and without unreasonable delay any reasonable purchase of . . . goods in substitution for those due from the seller." The buyer can then recover damages measured by the difference between the contract price and his actual cover price, together with the expense of covering. ${ }^{59}$ Unlike market-price damages, the cover measure is individualized. It turns not on a run of transactions between buyers and sellers as a class, but on the specific transaction in which the injured buyer actually engaged.

If a contract involves goods that are homogeneous and readily available on the market, the cover measure, though objective, will vindicate the buyer's subjective expectation: In such cases, when the buyer learns of the breach he can go into the market and obtain identical goods. If he does so, and recovers damages measured by the difference between the cover price and the contract price, he will end up with the very goods he contracted for at the very price he contracted to pay..$^{60}$

Moderately differentiated goods. Suppose that the goods are not homogeneous, but moderately differentiated, as in the following case:

Impala Buyer. On July 1, 1984, Buyer, a teacher living in Ann Arbor, agrees to purchase a 1980 Impala from Seller, an Ann Arbor engineer, for $\$ 7,000$. Seller is awaiting delivery of a new Peugeot, and promises delivery on July 15. On July 15, Seller notifies Buyer that she has decided to cancel her Peugeot purchase and keep the Impala.

One remedy available to Buyer is market-price damages. When applied to differentiated commodities, however, "market price" in

58. See UnIf. Sales Act $\S 67$ (act withdrawn 1951); D. DOBbS, HandBook ON THE LAW OF REMEDIES 870 (1973).

59. The buyer is also entitled to other incidental damages and to consequential damages.

60. It is true that the buyer will bear the cost of prosecuting any necessary lawsuit, but nonrecovery of litigation costs is based on an independent social policy which would apply even if damages were directly measured by the buyer's subjective valuation. 
the legal sense is not a real figure but a standardized construct. For example, it seems highly unlikely that there was an established market price for ' 80 Impalas in Ann Arbor on July 15, 1984. In fact, it is highly unlikely that any ' 80 Impala was sold in Ann Arbor on July 15 , or for that matter, during July 13-17. Even if such a sale had occurred, the Impala probably would have differed significantly from Seller's. Thus the "market price" of a differentiated good like a used car is not a real datum, but a construct arrived at by extrapolation from prices in like sales by like sellers to like buyers at like times in like places. ${ }^{61}$

Now assume that in Impala Buyer this process of extrapolation yields a "market price" of $\$ 7500$. Under the market-price measure of damages, Buyer would be entitled to recover $\$ 500$. Assume further, however, that Buyer thought that Seller's Impala was special-it grabbed him, or it purred, or it reminded him of the car he drove in college-and he valued the car at $\$ 8500$; a not-unlikely scenario, considering the abstract manner in which market price is determined. ${ }^{62}$ While the expectation principle then seems to require damages of $\$ 1500$, the law makes no provision for measuring damages on this basis, because a remedy in which the amount of damages depended on a direct measurement of the plaintiff's subjective valuation would be subject to little or no objective control and would entail grave administrative problems. There are, however, two alternative remedial techniques that can protect the buyer's expectation while avoiding direct measurement of his subjective valuation.

One of these techniques is specific performance. Traditionally, a buyer's right to specific performance in a contract for the sale of goods turned on whether the goods were "unique."63 Essentially,

61. See U.C.C $\$ 2-713$ official comment 3 (1977):

$[W]$ here no market price is available, evidence of spot sale prices is proper. Where the unavailability of a market price is caused by a scarcity of goods of the type involved . . . opinion evidence as to the value of the goods would be admissible in the absence of a market price....

See also id. § 2-723(2):

If evidence of a price prevailing at the times or places described in this Article is not readily available the price prevailing within any reasonable time before or after the time described or at any other place which in commercial judgment or under usage of trade would serve as a reasonable substitute for the one described may be used, making any proper allowance for the cost of transporting the goods to or from such other place.

62. For a valuable analysis of the role of subjective elements in contract remedies, in terms of the economic concept of consumer surplus, see Harris, Ogus \& Phillips, Contract Remedies and the Consumer Surplus, 95 LAw Q. REv. 581 (1979).

63. See, e.g., D. DOBBS, supra note 58 , at 884 . 
this is a standardized test based on the characteristics of the goods rather than the objectives and situation of the buyer. Today, section 2-716(1) of the Uniform Commercial Code gives a buyer the right to specific performance "where the goods are unique or in other proper circumstances." Section 2-716(3) gives a buyer the right to the comparable remedy of replevin "if after reasonable effort he is unable to effect cover for the goods or the circumstances reasonably indicate that such effort will be unavailing," and the goods were existing and identified when the contract was made or were later identified to the contract. $^{64}$ The official comment to section 2-716 states that Article 2 "seeks to further a more liberal attitude than some courts have shown in connection with the specific performance of contracts of sale." In this spirit, section 2-716 should be interpreted to permit the courts to consider the objectives and situation of the buyer as well as the characteristics of the goods.

This principle is easiest to apply when the buyer bases his claim for specific performance on individualized but objective elements. To illustrate, assume a class of moderately differentiated commodities, $A I-A 3$, and a contract to sell 1000 units of $A I$ to a merchant buyer. Some merchants may find $A 2$ or $A 3$ as satisfactory as $A 1$. Others may not. For example, if a merchant is purchasing for resale, $A 2$ or $A 3$ may not suffice if his customers look to him only for $A 1$. Similarly, if he plans to use the commodity in production, $A 2$ or $A 3$ may not suffice if he depends on special physical characteristics of $A 1$, or on a degree of reliability that he knows through an investment in testing and experience is met only by $A l$. Such buyers should be entitled to specific performance even though other buyers of $A I$ are not. In this type of case, at least, specific performance should rest not on the commodity's uniqueness as an abstract proposition, but on whether the individual buyer's objectives and situation make the commodity special to him. As the comment to section 2-716 states, "In view of this Article's emphasis on the commercial feasibility of replacement, a new concept of what are 'unique' goods is introduced under this section. ... The test of uniqueness under this section must be made in terms of the total situation which characterizes the contract." 66

64. Under U.C.C \$2-501(1) (1977), goods are "identified to the contract" (a) at the time the contract is made, if the contract is for the sale of goods already existing and identified, and (b) at the time the goods are shipped, marked, or otherwise designated as goods to which the contract refers, if the contract is for the sale of future goods.

65. Id. $\S 2-716$ official comment 1.

66. Id. $\$ 2-716$ official comment 2 . Even a contract for a homogeneous commodity may 
A related case arises where the buyer bases his claim to specific performance on subjective elements, as in Impala Buyer. This type of case is particularly likely when the buyer is a consumer rather than a merchant, because rational consumers, unlike rational merchants, may place a personal value on a commodity. Here, too, specific performance seems appropriate, although the issue is more difficult than in cases like the $A I$ hypothetical, where the buyer's preferences, while individualized, are objective. Nevertheless, while the right to specific performance in cases like Impala Buyer would depend upon a showing of subjective preferences, a direct measurement of subjective valuation would not be necessary. Furthermore, if specific performance is granted, the seller need only do what he promised to do. Thus, even if a court erroneously concludes that the buyer had subjective preferences which a damages award would not adequately reflect, there would be little or no unfairness to the seller.

Under the current state of the law it is not clear whether a consumer will be granted specific performance where a good is only moderately differentiated and where only subjective circumstances make substitutes inadequate. Moreover, specific performance, even if available, may be of no practical use if the buyer no longer wants the good at the time relief is ordered, or if the good has been resold to a third party. A second technique, however, may vindicate the expec-

be specifically enforced if the seller is a monopolist or for some other reason the commodity is not freely available in the market. See, e.g., Texas Co. v. Central Oil Fuel Co., 194 F. 1 (8th Cir. 1912) (crude oil); Kann v. Wausau Abrasives Co., 81 N.H. 535, 129 A. 374 (1925) (garnet); G.W.S. Service Stations, Inc. v. Amoco Oil Co., 75 Misc. 2d 40, 346 N.Y.S.2d 132 (N.Y. Sup. Ct. 1973) (gasoline); De Moss v. Conart Motor Sales, Inc., 34 Ohio Op. 535, 72 N.E.2d 158 (C.P. Summit Co. 1947), affd, 149 Ohio St. 299, 78 N.E.2d 675 (1948) (new autos).

Furthermore, even if a commodity is generally available, specific enforcement will be granted if the commodity is not available promptly or in the local marketing area. See Bomberger v. McKelvey, 35 Cal. 2d 607, 615-17, 220 P.2d 729, 735-36 (1950)(salvaged plate glass and skylights); Poltorak v. Jackson Chevrolet Co., 322 Mass. 699, 79 N.E.2d 285 (1948) (dictum)(automobiles); Cumbest v. Harris, 363 So. 2d 294 (Miss. 1978)(stereo components).

Output and requirement contracts may also be specifically enforced even though they involve homogeneous goods. See, e.g., Laclede Gas Co. v. Amoco Oil Co., 522 F.2d 33 (8th Cir. 1975). In these cases, the formation of the contract itself implies concern over availability. In addition, damages for a present breach may be very difficult to measure.

An often-quoted formulation is that specific performance of contracts for the sale of goods will be granted:

where the buyer shows that he is unable by reason of the nature of the subject, the conditions of the market, or other circumstances, to procure an article substantially similar to the one which he contracted to buy, or that the delay, expense and difficulties incidental to procuring such an article will entail serious inconvenience, loss or hardship, or that he stands in such a relation to the article that manifest justice will not be done unless performance is decreed.

Poltorak v. Jackson Chevrolet Co., 322 Mass. 699, 700, 79 N.E.2d 285, 285-86 (1948). 
tation of a buyer of a differentiated good without directly measuring his subjective valuation: The buyer could measure damages by the difference between the contract price and the cover price of a commodity that he purchased in good faith as a substitute. The cover purchase then serves as an objective surrogate for the buyer's subjective utility.

It might be objected that this approach would encourage the buyer to engage in opportunistic behavior by making a deliberately extravagant purchase. This seems unlikely. A rule that creates the possibility of opportunism does not necessarily lead to opportunism. Moreover, the requirement that the buyer actually make a substitute purchase serves not only as an objective surrogate for the buyer's subjective utility, but as an objective control on opportunism. Because litigation involves cost and risk, self-regard will likely keep the buyer from making an opportunistic purchase in the hope that ultimately the law will make the seller pay. In addition, courts may exercise direct control over opportunism by reviewing the buyer's good faith, which could include a review of whether it was rational for the buyer to treat the second purchase as a substitute for the first. ${ }^{67}$ In this connection, the buyer's ability to act opportunistically would be limited by the need to show that the second commodity was in fact a substitute for the first, and did not instead reflect an altered utility or a different set of values than those that led to the original contract. ${ }^{68}$

67. On the relationship between good faith and rationality, see Sam Wong \& Son v. New York Mercantile Exchange, 735 F.2d 653 (2d Cir. 1984) (Friendly, J.). The court there held that the rationality of a decision by the Board of Governors of the Exchange was relevant in determining whether the Board had acted in good faith. Id. at 671,677. By "rationality," the court stated, it meant

only a minimal requirement of some basis in reason-not a showing that the . . . action constituted the optimal response. Absent some basis in reason, action could hardly be in good faith even apart from ulterior motive. See [the decision of the court below, $571 \mathrm{~F}$. Supp. at 1553 ("the kind of reckless and virtually irrational exchange action that might independently support an inference of bad faith.").

Id. 678 n. 32.

68. For example, in Valley Die Cast Corp. v. A.C.W., Inc., 25 Mich. App. 321, 181 N.W.2d 303 (1970), A.C.W. had purchased from Valley Die Cast a car-wash sysiem in which cars were washed in place with high-pressure water jets. The system proved defective, and A.C.W. replaced it with a more expensive system that washed cars with brushes as they moved along a conveyor. A.C.W. apparently could have replaced the Valley Die Cast system with a comparable pressure system made by another manufacturer, but chose not to do so. The trial court ruled that A.C.W. had not covered, because it had "put an entirely different system in," id. at 337,181 N.W.2d at 311 , and the appellate court affirmed. Cf. Goodell v. K.T. Enterprises, Ltd., 394 So. 2d 1087 (Fla. Dist. Ct. App. 1981) (breach of contract to sell continuous-belt conveyor system for making pizza; cover "of same general type" sufficient). See also J. White \& R. SUmmers, HaNDBOOK of the LAw UNDER THE UNIFORM COMMERCIAL CODE 222 (2d ed. 1980): 
Another possible objection to this approach arises out of section 2-712 of the Code, which speaks of a "reasonable" purchase of substitute goods. This language is susceptible to two very different interpretations. Under one interpretation, section 2-712 would be satisfied only by a purchase that would have been made by a reasonable person who was placed in the buyer's situation but who had no special personal values. Under a second interpretation, at least as regards consumers, the application of section 2-712 would involve dividing the process of cover into two stages-the search for a substitute, and the actual purchase. For the search, the buyer's conduct would be judged on an objective-_"reasonable"-basis, since he is at fault if his search is not reasonably thorough. ${ }^{69}$ For the actual purchase, however, the buyer's conduct would be judged on the basis of whether he acted reasonably given his special values; whether, in short, he made a good faith substitute purchase. ${ }^{70}$ The second interpretation is not only preferable as a matter of policy, but is also strongly supported by the official comment:

[Section 2-712] does not limit cover to merchants .... It is the vital and important remedy for the consumer buyer as well. Both are free to use cover: the domestic or non-merchant consumer is required only to act in normal good faith while the merchant buyer must also observe all reasonable commercial standards of fair dealing in the trade, since this falls within the definition of good faith on his part. ${ }^{71}$

If the aggrieved buyer will himself consume the cover goods as for example by the use of furniture or equipment in a business, the problem is more difficult. Should the damage recovery under $2-712$ be reduced because the cover machinery which the aggrieved buyer purchased is marginally more efficient? Because the waiting room furniture is slightly more attractive than that contracted for? We think the damage recovery should not be reduced unless the seller comes forward with persuasive evidence that the buyer will reap added profits because of the superior quality of the cover merchandise. To see that the buyer gets his full measure under 2-712 absent powerful evidence by seller, we would urge courts to construe 2-712 as a generous and relatively unfettered remedy for the aggrieved buyer. Of course it is possible that 2-712 will over-compensate an occasional buyer because the seller will be unable to prove that the buyer specially benefited from the added quality of the cover, but it seems equally likely that nonrecoverable legal fees and other costs of litigation will often offset any such benefit and that the more likely and more common consequence of 2-712's application is to leave the buyer short of the economic position that full and timely performance offered.

69. See Productora e Importadora de Papel v. Fleming, 376 Mass. 826, 383 N.E.2d 1129 (1978).

70. See J. White \& R. Summers, supra note 68, at 218-19; of. R.K. Cooper Builders, Inc. v. Free-Lock Ceilings, Inc., 219 So. $2 d 87$ (Fla. Dist. Ct. App. 1969) (discussed at note 135 infia).

71. U.C.C. § 2-712 official comment 4 (1977). 
Highly differentiated goods. Suppose, finally, that a contract involves highly, rather than moderately, differentiated goods. Market-price damages would then be unlikely to satisfy the expectation principle, because of the high degree of extrapolation necessarily involved. Cover will normally be unavailable by the very nature of the case. Under the traditional doctrine of uniqueness, however, the buyer of a highly differentiated commodity is normally entitled to specific performance, thereby vindicating his actual expectation. ${ }^{72}$

In summary, the Code has moved very far to protect a buyer's actual expectation, by providing cover damages and liberalizing the tests for specific performance. The Code should be interpreted in the same spirit, by administering these remedies with regard for the buyer's objectives and situation, and, at least where the buyer is a consumer, his subjective preferences and good faith as well.

\section{Breach by the buyer.}

The obligation of a buyer of goods is normally limited to the payment of money. As a result, if the buyer breaches the seller's actual expectation can normally be satisfied without taking his subjective value into account, provided the seller's remedies are individualized. Pre-Code law usually limited the seller to standardized market-price damages. ${ }^{73}$ In parallel to its treatment of buyers, the Code perpetuated this remedy but also introduced several individualized alternatives. First, the Code supplied the seller with a counterpart to the buyer's remedy of cover. Under section 2-706, if the buyer defaults the seller may resell the goods and, if he does so in good faith and in a commercially reasonable manner, he can recover the difference between the resale price and the contract price. Second, the Code supplied the seller with a counterpart to the buyer's remedies of specific performance and replevin. Under section 2-709(1), the seller can recover the price of goods identified to the contract if, after reasonable effort, he cannot resell at a reasonable price, or if the circumstances reasonably indicate that he will be unable to do so.

72. This is not to say that such commodities do not have a market price. As the discussion of Impala Buyer shows, except in the case of homogeneous commodities legal market price is never anything more than a construct based on extrapolation. The difference, for this purpose, between moderately and highly differentiated commodities is therefore a difference of degree rather than kind. So, for example, the legal market price of a Turner might be derived by extrapolating from recent sales of other Turners and recent trends in the art market generally, together with expert testimony comparing the Turner in question to those recently sold.

73. See UNIF. SAlEs ACT $\S \S 63,64$ (act withdrawn 1951). 
However, in many cases even these formulas will not satisfy the expectation principle. Take the following hypothetical:

Paper Buyer. Seller is in the office supply business, selling to large users. Buyer is a financial corporation. On May 1, Seller and Buyer enter into a contract for the sale of 100 tenream cases of a standard grade of typing paper at a price of $\$ 4,000$, delivery on July 1 , and payment on August 1 . On July 1, Buyer repudiates.

If the law is to put Seller in as good a position as if the contract had been performed, he must have the right to measure his damages, in an individualized manner, by his lost net proceeds-that is, by the difference between the contract price and his out-of-pocket cost of performance. This measure is necessary, first, because if the contract had been performed, it would have enriched Seller by the amount of the net proceeds. Second, unless the commodity is highly differentiated, Seller usually cannot replace the net proceeds by making a substitute contract, since normally any contract Seller made after the breach would have been made even if the breach had not occurred. The Uniform Sales Act was generally interpreted to permit only standardized market-price damages in such cases. ${ }^{74}$ Under section 2708(2) of the Code, however, if the market-price measure of damages "is inadequate to put the seller in as good a position as performance would have done then the measure of damages is the profit (including reasonable overhead) which the seller would have made from full performance by the buyer." Thus, section 2-708(2) allows the seller in cases like Paper Buyer to measure recovery under an individualized, net-proceeds formula. ${ }^{75}$ While this formula may be overly generous to the seller where the buyer is a consumer, ${ }^{76}$ section 2-708(2) sharply points up the movement, in the remedies area, from standardized to individualized principles.

74. See, e.g., Charles St. Garage Co. v. Kaplan, 312 Mass. 624, 45 N.E.2d 928 (1942).

75. See, e.g., Snyder v. Herbert Greenbaum \& Assoc., Inc., 38 Md. App. 144, 380 A.2d 618 (1977); Jericho Sash \& Door Co. v. Bldg. Erectors, Inc., 362 Mass. 871, 286 N.E.2d 343 (1972); Neri v. Retail Marine Corp., 30 N.Y.2d 393, 285 N.E.2d 311, 334 N.Y.S.2d 165 (1972); Sebert, Remedies Under Article Two of the Uniform Commercial Code: An Agenda For Review, 130 U. PA. L. REv. 360, 383-96 (1981). Compare Goetz \& Scott, Measuring Sellers' Damages: The Lost-Profits Puzzle, 31 STAN. L. REv. 323 (1979) (criticizing the rule adopted in these cases) with Eisenberg, The Bargain Principle and its Limits, supra note 12, at 792 n.133 (criticizing the analysis in Goetz \& Scott).

76. See Eisenberg, The Bargain Principle and its Limits, supra note 12, at 793-94. 


\section{Market-price damages as a floor.}

The last two sections have shown that to effectuate the expectation principle, remedies should be individualized. In apparent contradiction, some commentators have argued that market-price damages should set a floor under the plaintiff's recovery and that often such a floor can only be justified under a standardized approach to damages. ${ }^{77}$ I shall show in this section that in all but a few cases a market-price damages floor is justified even under an individualized approach, and that in those few remaining cases, marketprice damages should not be awarded.

Breach by the buyer. Let us begin with the following hypothetical, taken from an article by David Simon, who in turn drew upon an example in Restatement (First):

[Stock Problems.] $A$ contracts to sell to $B 1000$ shares of stock owned by $A$, at a price of $\$ 10$ per share. The shares are freely traded in the market. On the delivery date, when the market price is $\$ 6$ per share, $B$ breaches and refuses to accept delivery. $A$ does not supply any proof that he sold at $\$ 6$ per share or suffered any other actual loss. ${ }^{78}$

In analyzing this hypothetical, Simon argues that $A$ should recover $\$ 4,000$, and suggests that under an individualized approach $A$ would recover $\$ 4,000$ only if he could prove that as a result of $B$ 's breach he was compelled to sell the stock at $\$ 6$ per share or less. ${ }^{79}$ The argument is right, ${ }^{80}$ but the suggestion is wrong. Simon here confuses a wealth effect and an income effect. If $A$ did not sell the stock at $\$ 6$ per share or less, he may not have realized a $\$ 4,000$ loss in income, but he has clearly lost $\$ 4,000$ in wealth, and therefore should recover that amount under an individualized approach regardless of what he did with his stock. Call the corporation whose stock is involved $C$. Since $C$ 's stock is homogeneous and freely traded, there is no legal connection between the $C$ stock that $A$ owned on the contract date and the $C$ stock he must deliver to $B$. Suppose, for example, $A$ had

77. See Simon, $A$ Critique of the Treatment of Market Damages in the Restatement (Second) of Contracts, 81 Colum. L. Rev. 80 (1981); Simon \& Novack, Limiting the Buyer's Market Damages to Lost Profits: A Challenge to the Enforceability of Market Contracts, 92 HARV. L. REv. 1395 (1979).

78. Simon, supra note 77 , at 87 . Simon uses a hypothetical concerning stock in order to invoke traditional common law damage rules rather than Article 2 of the Code. Id. at 87 n.40. Since virtually any sale of personal property today is governed directly or indirectly by Article 2, I will treat the problem as if Article 2 applied.

79. Id. at 87. Simon uses the term "subjective" for the the approach I call individualized. Id. at $82-84,88$.

80. See U.C.C. § 2-708(1) (1977). 
not owned any $C$ stock on the contract date. He still could have acquired 1,000 $C$ shares on the delivery date, used those shares to fill his contract with $B$, and increased his wealth by $\$ 4,000$. As it happens, $A$ did own 1,000 shares of $C$ stock on the contract date, but no rule of law required $A$ to fill his contract with $B$ by delivering those particular shares. On the contrary, $A$ was perfectly free to go into the market on the delivery date, buy 1,000 new shares of $C$ stock, turn a $\$ 4,000$ profit by filling his contract with the new shares, and retain his old $C$ stock. ${ }^{81}$ Indeed, market-price damages are calculated as if $A$ did just that: Under the market-price measure, a seller does not recover the difference between the contract price and his original cost for the commodity, but rather the difference between the contract price and the market price of the commodity at the date of the breach. As a result of $B$ 's breach, $A$ lost the opportunity to turn a $\$ 4,000$ profit by buying $C$ stock on the delivery date and selling it to $B$. Under an individualized approach, therefore, $A$ is entitled to $\$ 4,000$ damages regardless of what he did with his old 1,000 $C$ shares after $B$ 's breach.

The same conclusion can be reached through another, closely related analysis. Whenever there is a ready market for a commodity, a decision to hold rather than sell the commodity is functionally equivalent to a decision to invest in the commodity at the prevailing market price. For example, if Corporation $C$ common stock sells for $\$ 6$ per share on January 15 , a person who holds $C$ common on January 15 and does not sell, effectively makes a decision to invest $\$ 6$ per share that day in $C$ common. So in the Stock Problems hypothetical, if $A$ continued to hold his 1,000 shares of $C$ stock after the delivery date, he effectively made a series of daily decisions to invest in 1,000 shares of $C$ stock at the prevailing daily market prices. Both the positive and the negative risks of those investment decisions should lie with $A$, and accordingly, it is irrelevant, in $A$ 's action against $B$, whether $C$ stock went up or down after the delivery date, or what $A$ did with the stock. $^{82}$

In short, under an individualized approach $A$ should recover $\$ 4,000$ without showing that he sold his stock at $\$ 6$ per share or less. Indeed, $A$ should recover $\$ 4,000$ even if, by reason of a later market rise, he sold his $C$ stock at more than $\$ 6$ per share, or even if $A$ still

81. See United States v. Burton Coal Co., 273 U.S. 337, 340 (1927); Spencer Kellog \& Sons v. Providence Churning Co., 45 R.I. 180, 182, 121 A. 123, 124 (1923).

82. See Friedman Iron \& Supply Co. v. J.B. Beaird Co., 222 La. 627, 63 So. 2d 144 (1953). 
owned his $C$ stock at the time of trial and it was then worth $\$ 10$ per share. To put the matter more generally, in any contract for the sale of a readily marketable homogeneous commodity, the seller always incurs damages at least equal to the spread between contract price and market price, because, had performance occurred, he could always have turned a profit equal to that spread by filling the contract through a contemporaneous market purchase. Accordingly, even under an individualized approach, market-price damages should always set a floor under the seller's recovery in contracts for the sale of such a commodity, except where the seller himself forgoes the market-price measure by identifying goods to the contract and reselling them promptly for the very purpose of fixing damages. ${ }^{83}$

Difficulties may arise, however, where the commodity is differentiated. Essentially, these difficulties involve two sorts of cases. In the first type, the seller has made a contract to purchase the commodity from a third person, and the price under that contract exceeds the market price at the time of breach. Take, for example, the following hypothetical, also drawn from an illustration used by Simon:

Third-Party Supplier. $A$ contracts to sell to $B$ a used grinding mill for $\$ 10,000$. $A$ had previously contracted to purchase the mill from $C$ for $\$ 8,000$. On the delivery date the market value of the mill is $\$ 6,000$. $B$ refuses to accept delivery. ${ }^{84}$

Normally, $A$ should recover damages of $\$ 4,000$, representing the swing between making a $\$ 2,000$ profit, by buying the mill at $\$ 8,000$ and selling at $\$ 10,000$, and incurring a $\$ 2,000$ loss, by buying for $\$ 8,000$ a mill worth only $\$ 6,000 .^{85}$ Suppose, however, that $C$ excuses $A$ from performing, so that $A$ does not incur the $\$ 2,000$ loss. Should $A$ then be limited to damages of $\$ 2,000$ lost profit? Simon argues that $\$ 4,000$ market-price damages are still appropriate. ${ }^{86}$ To analyze this problem, we must ask why $C$ would excuse $A$. One possibility is that $C$ expects something in return, such as reciprocal treatment in future dealings. In that case, the excuse is not cost-free to $A$, and while the precise cost must be indeterminate, it can be presumptively valued at $\$ 2,000$. Or, $C$ may give up his claim against $A$ as a com-

83. See U.C.C. § 2-706 (1977); notes 93-102 infra and accompanying text.

84. See Simon, supra note 77 , at 89.

85. See United States v. Burton Coal Co., 273 U.S. 337, 340-41 (1927); Ernesto Foglino \& Co. v. Webster, 244 N.Y. 516, 155 N.E. 878 (1926)(per curiam). See also the cases cited at note 105 infra (counterpart problem on breach by seller).

86. Simon, supra note 77 , at 89 . 
passionate act to relieve the hardship caused by $B$ 's breach. In that case, if $A$ is made whole by a $\$ 4,000$ judgment against $B$, he would be morally obliged to pass through $\$ 2,000$ of that amount to $C$. Indeed, $A$ may implicitly promise to make such a pass-through. If $B$ pays $A$ $\$ 4,000$ and $A$ does what he should, therefore, both $A$ and $C$ would end up just where they would have been if $B$ had performed. ${ }^{87}$ In both these cases, damages of $\$ 4,000$ would be justified under individualized principles.

On the other hand, $C$ may release $A$ because $C$ values the mill at $\$ 8,000$ or more. Since a used grinding mill is relatively differentiated, the $\$ 6,000$ market price is likely to be derived by extrapolating from sales of similar mills. $C$ may place a special value on his own mill because, say, it has special characteristics suited to his needs, or it is already installed, or he knows it is not a lemon. Here $C$ will expect nothing more of $A, A$ will have lost wealth of only $\$ 2,000$, and damages of $\$ 2,000$ will put $A$ where he would have been if $B$ had performed. Similarly, suppose that $A$ settles $C$ 's claim for $\$ 1,000$, incurring legal expenses of $\$ 500$ in the process. Here too, $C$ presumably expects nothing more from $A$, and under an individualized approach $A$ should recover only $\$ 3,500$ ( $\$ 2,000$ lost profit plus $\$ 1,500$ out-of-pocket costs).

Simon argues that in cases like the Third-Party Supplier hypothetical the seller should recover $\$ 4,000^{88}$ regardless of the circumstances "to deter breach . . . , to enable the market to function in an orderly and predictable fashion, to avoid burdensome complications of proof, to simplify and make uniform the law, to provide a readily predictable result for businessmen ...., and to facilitate settlements."89 The emphasis on deterring breach runs counter to the traditional contract-law approach that damages should be based not on deterrence but on compensation. In any event, expectation damages will not fail to deter breach merely because they are measured in an individualized manner. The remaining arguments, which are those invoked in support of any kind of standardized contract-law rule, unrealistically exaggerate the difficulty of administering individualized damage rules in the present context. ${ }^{90}$

The second difficult type of case involving differentiated goods

87. Ernesto Foglino \& Co. v. Webster, 244 N.Y. 516, 155 N.E. 878 (1926) (per curiam). Contra Nobs Chemical, U.S.A. v. Koppers Co., 616 F.2d 212 (5th Cir. 1980).

88. Simon, supra note 77 , at $89-90$.

89. Id. at 85 (footnote omitted).

90. See id. at 91-92. 
arises where a seller who resells the goods within a reasonable time after breach nevertheless sues for market-price damages, and the buyer shows that the resale price was higher than the market price, so that damages measured by the market-price measure would exceed damages measured by the resale-price measure. In determining whether market-price damages should be a floor in such cases, we must examine why a spread between the market and resale prices might exist.

One possible reason is that a resale price is a factual datum, while market price is a construct and therefore subject to error. If this factor causes the spread, the seller should recover only resale-price damages, because an erroneous measure should not be used when an accurate measure is at hand.

A second possible reason is that section 2-708 of the Code measures the seller's market-price damages as of the date for tender, ${ }^{91}$ while under section 2-706 the seller can measure resale-price damages by a resale made within a reasonable time after breach. ${ }^{92}$ Therefore, the market price may be less than the resale price because the commodity's price-level rose between the time for tender and the time of resale. In such a case, the seller should also receive only resale-price damages. By virtue of section 2-706, if a seller resells within a reasonable time after breach, the breaching buyer bears the burden of a decline in the commodity's price-level between the tender date and the resale date, because the seller can sue for resale-price damages which will include that decline. Presumably, this rule reflects an assumption that the parties expect the buyer to bear the risk of price changes within a reasonable time after breach. Under that assumption, the buyer should be entitled to the benefit of a rise in the commodity's price-level, just as he suffers the detriment of a decline.

A third possible reason for a spread between the resale price and the market price of a differentiated commodity is that the resale may be made to a buyer who either lacks knowledge or bargaining skills, or has a special utility for the commodity. Peters has argued in favor of permitting the seller to recover market-price damages in such cases, on the ground that this measure encourages resales, "since it guarantees to the injured party that he will not lose all remedy in the event of an unusually favorable substitute contract." ${ }^{\text {93 }}$ However, if

91. U.C.C. $\$ 2-708(1)$ (1977).

92. Id. $\S 2-706(2)$ and official comment 5.

93. Peters, Remedies for Breach of Contract Relating to the Sale of Goods Under the Uniform Commercial Code: A Roadmap for Article Two, 73 YALE L.J. 199, 261 (1963). 
the seller can make an unusually favorable resale contract he will do so even if his damages are thereby reduced. Say the contract price is $\$ 10,000$, the market price is $\$ 7,000$, the seller has an opportunity to resell for $\$ 8,750$, and the probability of collecting damages from the buyer is $\mathrm{p}$, which is less than one. If the seller resells, the expected value of his total recovery is $\$ 8,750$ plus $\$ 1,250(p)$. If he does not resell, he ends up with an expected value of $\$ 7,000$ (the market price of the commodity) plus $\$ 3,000(\mathrm{p})$. Since his expected recovery is greater if the resale is made (as it would be in every case where the resale price is unusually favorable) a rational seller will resell at a favorable price even though to do so would reduce his damages. ${ }^{94}$

How the Code treats this kind of case is not as clear as how it should be treated in principle. At one time section 2-703 of the Code (which serves as an index to the seller's remedies) provided that a seller could recover market-price damages under section 2-708 "so far as any goods have not been resold." this language. The Code's Editorial Board stated that the deletion was intended "to make it clear that the aggrieved seller is not required to elect between [resale-price] damages under Section 2-706 and [market-price] damages under Section 2-708."96 This explanation can be interpreted to permit the seller to choose market-price damages even when he has resold at a price in excess of market. However, nothing in the text of the Code requires such an interpretation. On the contrary, section 1-106 provides that remedies under the Code are to be "liberally administered to the end that the aggrieved party may be put in as good a position as if the other party had fully performed . . . ."97 Furthermore, the official comment to the Code's counterpart provisions on buyer's remedies states that if a buyer covers he is limited to cover damages, ${ }^{98}$ and no sensible distinction exists in this regard between cover and resale. ${ }^{99}$ Even the comment to section 2-703 does not pick up the language of the Editorial

94. The expected value of a transaction involving risk is "the magnitude of a potential loss or gain multiplied by the probability of the loss or gain occurring." A.M. POLINSKY, AN INTRODUCTION TO LAW AND ECONOMICS 27 (1983); see H. RAIFFA, DECision ANALysis 9 (1968). The illustration in the text is a variation of an illustration suggested to me by Alan Schwartz.

95. U.C.C. § 2-703 (1955) (amended 1977); see Peters, supra note 93, at 260.

96. American Law Institute and National Conference of Commissioners on Uniform State Laws, 1956 Recommendations of the Editorial Board for the Uniform Commercial Code 73 (1957); Peters, supra note 93 , at 260 .

97. U.C.C. $\S 1-106(1977)$.

98. Id. § 2-713 official comment 5; see notes 109-111 infra and accompanying text.

99. See U.C.C. § 2-712 official comment 1 (1977)(equating the two remedies). 
Board's report, but instead says, "This Article rejects any doctrine of election of remedy as a fundamental policy and thus the remedies are essentially cumulative in nature and include all of the available remedies for breach. Whether the pursuit of one remedy bars another depends entirely on the facts of the individual case."100 Thus the Board's language may have meant only that a pleading could request both market-price and cover damages, leaving it to the court, on all the facts developed at trial, to determine which of the requested remedies was appropriate. White and Summers suggest that the Board may have simply wanted to make clear that a seller who resold in a manner that failed to meet the requirements of section 2-706 could still recover damages under section $2-708 .^{101}$

Thus the Code should be interpreted to limit the seller to resaleprice damages if, within a reasonable time after the breach, he resells a differentiated commodity at a price in excess of the market price on the delivery date. ${ }^{102} \mathrm{~A}$ different result should follow, however, if the seller resells after a reasonable time has elapsed. In such cases it may be inferred that the spread between market price and resale price occurred because the the commodity's market value rose during the relevant period. However, a resale after the expiration of a reasonable time would not satisfy the conditions of section 2-706. Therefore, the seller could not get resale-price damages, and so bears the risk of a change in the commodity's price level after the breach. Since the seller bears that risk, he, rather than the buyer, should benefit from a rise in the commodity's price level. A rule that in such cases the seller is not limited to damages based on the lower resale price will achieve this result.

Breach by the Seller. The analysis of damages on breach by the seller parallels that on breach by the buyer. First, in all but a very few cases, the market-price measure should constitute a floor for a buyer's recovery on breach by a seller even under an individualized approach. Take, for example, the following hypothetical:

Copper Trouble. Seller is a copper-mining company. Buyer manufactures copper tubing, and does not engage in copper trading. Seller agrees to sell Buyer 1000 tons of copper at $\$ 60$ per ton. On the delivery date, when the market

100. Id. § 2-703 official comment 1 (emphasis added).

101. J. WHITE \& R. SUMmERS, supra note 68, at 272.

102. See Coast Trading Co. v. Cudahy Co., 592 F.2d 1074, 1081-83 (9th Cir. 1979); J. WHITE \& R. SUMMERS, supra note 68, at 271-73. 
price is $\$ 80$ per ton, Seller tells Buyer he does not intend to perform. In the interim, Buyer has unexpectedly reduced its output of copper pipe, and therefore does not need Seller's copper.

Buyer should recover market-price damages of $\$ 20,000$ despite his new circumstances, since he could either have taken delivery of Seller's copper at $\$ 60,000$ and resold it at $\$ 80,000$, or assigned his rights under the contract for $\$ 20,000 .^{103}$ Buyer may not usually engage in copper trading, but nothing stops him from making a copper trade, and in a case like Copper Trouble a rational buyer would either assign or take delivery and resell. The same analysis would apply if Buyer originally intended to hold the copper for investment and some time after the delivery date the price of copper fell below the contract price. Whatever the buyer's intention at the time of contract-formation, he remained free to change his mind later. In any event, had the buyer accepted the copper and held it, he, not the seller, would have borne the risks and benefits. The seller is no more entitled to a reduction in damages when the price of a homogeneous commodity goes down after the delivery date than the buyer is entitled to an increase when the price goes up. ${ }^{104}$ To put the matter more generally, in any contract for the sale of a readily marketable homogeneous commodity, the buyer always incurs damages at least equal to the spread between contract price and market price, because had performance occurred he could have turned a profit equal to that spread by promptly reselling the commodity. Accordingly, market-price damages should always set a floor under the buyer's recovery in contracts for the sale of such a commodity, even under an individualized approach, unless the buyer himself forgoes the market-price measure by making a prompt replacement purchase and treating it as cover.

Difficulties may arise, however, with differentiated commodities. As with seller's breach, these difficulties may involve two sorts of cases. In the first type of case, before the delivery date the buyer contracts to resell the commodity, and the price under that resale contract is less than the market price on the delivery date. Take, for example, the following hypothetical:

Third-Party Purchaser. $A$ contracts to sell to $B$ a used

103. Cf. United States v. Burton Coal Co., 273 U.S. 337 (1927) (counterpart problem on breach by buyer).

104. Cf. Friedman Iron \& Supply Co. v. J.B. Beaird Co., 222 La. 627, 63 So. 2d 144 (1953) (counterpart problem on breach by buyer). 
grinding mill for $\$ 10,000$. Before delivery is due, $B$ contracts to sell the mill to $C$ for $\$ 12,000$. On the delivery date the mill has a market value of $\$ 14,000$. $A$ refuses to make delivery.

The analysis here resembles that applied to Third-Party Supplier. Normally, $B$ should recover damages of $\$ 4,000$, representing the swing between the $\$ 2,000$ profit he would have made if $A$ had performed and the $\$ 2,000$ liability he has now incurred. ${ }^{105}$ If, however, $B$ settles $C$ 's claim for, say, $\$ 1,000$, his damages should be limited to the total of his lost profit of $\$ 2,000$, the $\$ 1,000$ he paid to $C$ in settlement, and his transaction costs. ${ }^{106}$ It has been argued that this result would leave $A$ unjustly enriched. ${ }^{107}$ Contract law, however, has traditionally viewed gains from default as unjust enrichment only if they are derived from benefits conferred or services rendered by the injured party. ${ }^{108}$

The second type of problem involving differentiated goods arises when the buyer covers at a price lower than market. For the reasons applicable to the counterpart case where the seller resells at a price higher than market, ${ }^{109}$ the covering buyer should receive only cover

105. See Brightwater Paper Co. v. Monadnock Paper Mills, 161 F.2d 869, 872 (1st Cir. 1947) (semble); Stebel v. United States, 69 F. Supp. 221, 223 (Ct. Cl. 1947); Floyd v. Mann, 146 Mich. 356, 369-70, 109 N.W. 679, 684 (1906); Iron Trade Products Co. v. Wilkoff Co., $272 \mathrm{~Pa} .172,177-78,116$ A. 150, 151-52 (1922); Clinton Oil \& Mfg. Co. v. Carpenter, 113 S.C. 10, 18-19, 101 S.E. 47, 50 (1919); Tennessee Fertilizer Co. v. Int'l Agricultural Corp., 146 Tenn. 451, 463-71, 243 S.W. 81, 85-87 (1922); Coombs \& Co. v. Reed, 5 Utah 2d 419, 303 P.2d 1097 (1956); of. cases cited in note 85 supra (counterpart problem on breach by buyer). A number of cases appear to look the other way. See Texas Co. v. Pensacola Maritime Corp., 279 F. 19, 30 (5th Cir. 1922); Kaye v. Eddystone Ammunition Corp., 250 F. 654 (E.D. Pa. 1918), Bernhardt Lumber Co. v. Metzloff, 113 Misc. 288, 298-301, 184 N.Y.S. 289, 294-96 (N.Y. Sup. Ct. 1920); Isaacson v. Crean, 165 N.Y.S. 218 (N.Y. App. Term. 1917); Foss v. Heineman, 144 Wis. 146, 128 N.W. 881 (1910). In Texas Co., Bemhardt, and Isaacson, either the original contract designated the ultimate purchasers, Isaacson, 165 N.Y.S. at 218-19, or the buyer was a middleman and the original contract was a requirements contract, $T_{\text {exas }} C_{0 .}, 279$ F. at 23. In Foss the buyer was not liable to his purchaser for nondelivery, because he was obliged to deliver only what he might receive from the seller, 144 Wis. at 147,128 N.W. at 882.

106. See Compania Naviera Asiatic v. The Burmah Oil Co., No. 74-2025, slip op. at 68-69 (S.D.N.Y. Apr. 27, 1977); Simon \& Novack, supra note 77, at 1427-36. This analysis is inapplicable where the commodity is homogeneous and freely traded, since in that case there is no economic or legal connection between the $A-B$ and $A-C$ transactions. See notes 78-83 supra and accompanying text.

107. See Simon \& Novak, supra note 77, at 1433-34.

108. See Foss v. Heineman, 144 Wis. 146, 152, 128 N.W. 881, 884 (1910); 1 G. PALmer, THE LAW OF RESTITUTION 438 (1978). But see Friedmann, Restitution of Benefils Oblained Through the Appropriation of Property or the Commission of a Wrong, 80 Colum. L. REv. 504, 513-15 (1980).

109. See notes $91-102$ supra and accompanying texts. 
damages. ${ }^{110}$ Indeed, this problem is easier to deal with under the Code than is its counterpart. The official comment to section 2-713, which governs the buyer's market-price damages, states that the section "provides a remedy which is completely alternative to cover under [section 2-712] and applies only when and to the extent that the buyer has not covered."11

\section{B. Contracts Involving the Provision of Services}

I shall now turn to contracts involving the provision of services. For convenience, I shall sometimes refer to the party who provides services as the seller or service-provider, and the party to whom services are provided as the buyer.

\section{Breach by the buyer.}

The obligation of a buyer of services, like that of a buyer of goods, is normally limited to the payment of money. As in the case of goods, therefore, if the buyer breaches, the seller's actual expectation can normally be satisfied without taking his subjective value into account, provided the seller's remedies are individualized.

110. It has been argued that restricting the buyer to cover-price damages would discourage a cover purchase, by causing the buyer to lose his remedy in the event of an unusually favorable cover contract. See Peters, supra note 93, at 259-61; notes 93-94 supra and accompanying text. However, the ability to make an unusually favorable cover purchase is just one of the possible reasons why cover damages may be less than market damages. Moreover, even where that is the reason for the spread, restricting the buyer to cover damages would seldom if ever dissuade a buyer from covering. If the buyer purchases for resale, he will invariably make a favorable cover contract even if his damages are thereby reduced. Say, for example, the contract price is $\$ 10,000$; Buyer has a contract to resell at $\$ 15,000$; the market price is $\$ 13,000$; Buyer could cover for $\$ 11,500$; and the probability of collecting damages from Seller is $\mathrm{p}$, which is less than 1. If Buyer covers, he has a present profit of $\$ 3,500$ plus a claim worth $\$ 1,500(p)$. If Buyer does not cover, he has a claim worth $\$ 5,000(p)$. Since $p$ is less than one, Buyer will cover.

It is true that if a buyer is purchasing for consumption or use, rather than for resale, and he covers at a price less than market, he will forgo a larger claim and end up with a claim that is worth less. Thus in the hypothetical, if Buyer is purchasing for consumption or use, he will forgo a claim of $\$ 3,000$ and end up with a claim of $\$ 1,500$. But that does not necessarily mean he will be dissuaded from covering. If Buyer wanted the contracted-for commodity when he made the contract, he probably still wants it when the cover transaction is available. In that case, he may cover even though his damage claim is reduced. For example, suppose Buyer values the commodity at $\$ 15,000$. If Buyer covers, he has consumer's surplus of $\$ 3,500$ plus a claim worth $\$ 1,500(\mathrm{p})$. If Buyer fails to cover, he has only a claim of $\$ 5,000(\mathrm{p})$. Buyer will cover.

111. U.C.C. $\$ 2-713$ official comment 5 (1977). This comment should be read to apply to homogeneous goods only where the buyer replaces from the market almost immediately, and treats the replacement purchase as cover, so that cover is merely an individualized application of market-price damages. See notes 78-83 supra and accompanying text. 
The established formula for measuring damages for breach by a buyer of services is based on the difference between the contract price and the seller's out-of-pocket cost of completion at the time of breach. This formula mirrors the net-proceeds measure afforded a seller of goods under section 2-708(2) of the Uniform Commercial Code. There is, however, an important difference between the rules governing goods cases and services cases. In goods cases, both the formula and its application are individualized, since the section 2708(2) net-proceeds measure is available only where the breach does not enable the seller to make a replacement sale that he could not otherwise have made. In contrast, in most types of services cases courts have applied the net-proceeds measure in a highly standardized fashion, without regard to the presence of a replacement sale.

Take, for example, the following hypothetical:

Busy Plumber. Plumber engages in the business of upgrading plumbing in old commercial buildings; he operates at full capacity, and must often turn down jobs. On January 1, Plumber enters into a contract to do a plumbing job for Owner 1 for $\$ 6000$, the work to begin on February 1 and to be completed in two weeks. On January 30 , Owner 1 repudiates the contract. On January 31, Plumber enters into a contract to do a plumbing job for Owner 2 for $\$ 7600$, the work to begin on February 1 and to be completed in two weeks. Plumber could not have accepted the job with Owner 2 but for the breach by Owner 1 . Plumber's out-of-pocket costs for performing his contract with Owner 1 would have been $\$ 3400$. His out-ofpocket costs for performing his contract with Owner 2 are $\$ 2900$. Plumber now sues Owner 1.

In assessing Plumber's recovery, the expectation principle would require the contract with Owner 2 to be taken as an offset, lest damages place him in a better position than performance would have done. In the past, however, the courts have usually not permitted such an offset. For example, in Grinnell Co. v. Voorhees, ${ }^{12}$ Grinnell entered into a contract with Willys Corporation under which Grinnell agreed to install a fire-extinguishing system in a Willys plant. When Grinnell had completed seventy-eight percent of the work, Willys became insolvent and fell into receivership. Durant Motor Company then purchased the Willys plant and employed Grinnell to complete the fire-extinguishing system. Although Willys paid Grinnell for the work it had done, and although Grinnell apparently made practically the same profits under the Durant contract that it would have made under the Willys contract, Grinnell sued the Wil-

112. 1 F.2d 693 (3d Cir. 1924). 
lys receivers to recover the profits it would have earned under the Willys contract had it been allowed to complete that contract. In measuring Grinnell's damages, the court refused to offset Grinnell's profits under the Durant contract against its loss of profits under the Willys contract. When a contract for services is breached, the court said, "the claim of the plaintiff accrues at once and the law does not inquire into later events," unless "personal services" are involved."113

In striking contrast, in cases where "personal services" are involved-that is, in contracts of employment-if the buyer (employer) breaches, the law reduces the damages of the seller (employee) not only by any replacement wages he actually earns, but by any wages he would have earned had he used reasonable efforts to find a replacement job. ${ }^{114}$ This difference between the employment and nonemployment cases is highly anomalous. For one thing, an employment contract is only a special case of a contract for the provision of services. For another, if the law must treat employment contracts differently than other services contracts, one would expect it to be more tenderhearted to employees than to business organizations.

Two kinds of arguments have been made in support of the tradi-

113. Id. at 695. Some of the cases that adopted this rule seem to have been based in large part on the erroneous notion that in determining a contractor's damages under the contract-price-minus-cost-of-completion formula, the court should count the value of the contractor's own labor as a cost, thereby diminishing his recovery. For example, in the leading case of Olds v. Mapes-Reeve Constr. Co., 177 Mass. 41, 58 N.E. 478 (1900), whose facts were very similar to those of Grinnell, the court stated:

In estimating the damages in the present case the auditor found that the actual cost of completing the work after the breach of the contract was $\$ 717.27 \ldots$. In making this estimate of the cost of completing the work, the auditor charged the plaintiffs with all labor and services which would have entered into it, whether personal to themselves or rendered by agents or employees . . . . In a contract of the kind before the court .... [ [ $t$ ] he labor or supervision may be personally performed by the contractor or may be furnished through agents or employees. In either case the value of it is all included for the benefit of the other party when the contractor is charged with the whole cost of completing the work, as an amount to be deducted from the contract price in estimating his damages.

Id. at 44,58 N.E. at 479.

Once this basic position is taken, it follows that the replacement contract, in which the contractor presumably makes use of his newly freed-up labor, should not affect the contractor's recovery: If the contractor's damages are reduced by the value of his labor even if he does not resell it, his damages cannot be reduced by the value of the same labor a second time if he does resell it. However, the basic position is erroneous. The value of the contractor's own labor should not be deducted from his recovery, since his cost of completion should include only out-of-pocket costs, not items of overhead. Insofar as the no-offset rule is a consequence of the basic position, it should fall with that position.

114. D. DOBBS, supra note 58, at 926. 
tional no-offset rule applied in nonemployment cases like Grinnell. One follows from a concept of business economics, and the other from a concept of reciprocity. The business-economics argument, advanced by Professor Patterson, is that, "As an enterpriser, [a] builder may take on an indefinite number of contracts and make a profit on all of them."115 This argument is empirically wrong. Factors such as managerial resources, working capital, and bonding limits constrain the number of jobs a contractor can take on. Of course, a contractor often can expand capacity within limits. In most cases, therefore, a buyer's breach may not enable a contractor to make a replacement contract he could not otherwise have made. Indeed, many cases that apply the traditional no-offset rule might well have reached the same result even if the rule had not been applied. ${ }^{116}$ That is no reason, however, to prohibit the buyer from establishing that, in his case, the breach enabled the seller to take on a replacement job that he could not otherwise have performed.

The reciprocity argument, advanced in Grinnell itself, is that "[i]t would not be just to give the defendant the benefit of a good contract and not charge him with the loss of a bad one when plaintiff had honestly used his skill, time, and capital."117 This argument rests on the tacit assumption that the defendant is not liable for the loss on a bad replacement contract. That assumption might be questioned: By way of analogy, if the employer breaks an employment contract and the employee incurs expenses in seeking a replacement job, those expenses are added to the employee's damages even if the search is unsuccessful. ${ }^{18}$ In any event, both the seller's damages and the offset should be measured by net proceeds - that is, by the difference between out-of-pocket expenses and the contract price-not by net profits. Many service contracts result in negative net profits, but few will be likely to result in negative net proceeds. It is therefore letting the tail wag the dog to deny an offset for a replacement contract that yields positive net proceeds, on the theory that a defendant should not bear the burden of (an extremely unlikely) replacement contract that yields negative net proceeds. Furthermore, negative-net-proceeds contracts might be distinguished from positive-net-proceeds

115. Patterson, Builder's Measure of Recovery for Breach of Contract, 31 ColuM. L. REv. 1286, 1306 (1931).

116. Even in Grinnell, it is conceivable that if Durant had not purchased the Willys plant, it might have built a new plant from scratch, with a Grinnell system.

117. Grinnell Co. v. Voorhees, 1 F.2d at 695; accord Olds v. Mapes-Reeve Constr. Co., 177 Mass. 41, 45, 58 N.E. 478, 479 (1900).

118. See, e.g., Mr. Eddie, Inc. v. Ginsberg, 430 S.W.2d 5, 11-12 (Tex. Civ. App. 1968). 
contracts on the grounds that they are not reasonably foreseeable (because so unlikely), and that they probably result from the seller's lack of skill, which the defendant should not have to subsidize. ${ }^{119}$

Finally, the reciprocity argument does not square with the courts' treatment of employment contracts in cases where the employee starts his own business during the unexpired term of the breached contract. The general rule is that the employee's recovery is reduced by what he has earned and can reasonably expect to earn in his new business during the unexpired term of the broken agreement. ${ }^{120}$ If the reciprocity argument were correct, it would apply to this case as well.

In short, the rule traditionally applied to nonemployment services contracts is triply anomalous: It is inconsistent with the expectation principle, with the rules governing contracts for the sale of goods, and with the rules governing a kindred class of contracts for the sale of services. Therefore, it is not surprising that the rule seems to be eroding. For example, in $M . \mathscr{F}^{2} R$. Contractors $\mathcal{E}^{2}$ Builders v. Michael ${ }^{21}$ the court said that if a contractor "could not have worked on another job or project unless he had been discharged from the performance of the defendant's contract, then the gains from the other employment or undertaking must be deducted from [its] damages." ${ }^{122}$ Similarly,

119. For an analysis based on foreseeability, see Vernon, Expectancy Damages for Breach of Contract: $A$ Primer and Critique, 1976 WASH. U.L.Q. 179, 213-15.

120. See Ridenour v. Kuker, 185 Neb. 321, 327, 175 N.W.2d 287, 291 (1970); Cornell v. T.V. Dev. Corp., 17 N.Y.2d 69, 74-75, 215 N.E.2d 349, 351-52, 268 N.Y.S.2d 29, 33-34 (1966); D. DOBBS, supra note 58, at 926-27.

121. 215 Md. 340,138 A.2d 350 (1958).

122. Id. at 355, $138 \mathrm{~A} .2 \mathrm{~d}$ at 358 (emphasis in original); see also Kearsarge Computer, Inc. v. Acme Staple Co., 116 N.H. 705, 709-10, 366 A.2d 467, 471 (1976); McMullen v. Wel-Mil Corp., 23 N.C. App. 736, 209 S.E.2d 507 (1974); 5 A. CoRBIN, supra note 52, §§ 1041, 1094 (1964).

H.A. Steen Industries, Inc. v. Richer Communications, 226 Pa. Super. 219, 314 A.2d 319 (1973), involved an analytically comparable problem. Steen had leased two billboards from Richer for a two-year term, but defaulted after several months. Judgment by confession was entered in Richer's favor for unpaid rentals, and Steen moved to open the judgment to introduce evidence showing that Richer had re-rented the billboards. The lower court declined to reopen, but its decision was reversed:

It is true that there are situations in which a non-breaching party is entitled to recover lost profits with no duty to mitigate damages. For example, where the product is manufactured, and two are as easily manufactured as one, a non-breaching seller may get two profits from the combination of one default and one sale. See, e.g., U.C.C. $\S 2-708(2)$. . . . Thus, in this case, if appellee had a potentially unlimited supply of billboards, so that it could accommodate as many customers as it could find . . . it would be entitled to lost profits without mitigation. . . .

There is no indication that appellee "had [such] other space," and the fact that the billboards were rather quickly re-leased indicates that it did not. 
the comment to section 347 of Restatement (Second) of Contracts adopts the rule that if an injured party makes substitute arrangements for the use of resources he would have needed to perform the original contract, the net profit from the substitute arrangements reduces his damages. The comment continues:

f. Lost volume. . . . Since entrepreneurs try to operate at optimum capacity ... it is possible that an additional transaction would not have been profitable and that the injured party would not have chosen to expand his business by undertaking it had there been no breach. It is sometimes assumed that he would have done so, but the question is one of fact to be resolved according to the circumstances of each case .... .

[Illustration] 16. $A$ contracts to pave $B$ 's parking lot for $\$ 10,000$. $B$ repudiates the contract and $A$ subsequently makes a contract to pave a similar parking lot for $\$ 10,000$. A's business could have been expanded to do both jobs. Unless it is proved that he would not have undertaken both, $A$ 's damages are based on the net profit he would have made on the contract with $B$, without regard to the subsequent transaction. ${ }^{123}$

Suppose now that a seller of services could have obtained a replacement job but did not. This problem has not been worked out in the context of nonemployment contracts, because under the traditional rule replacement jobs were irrelevant in that context. In the context of employment contracts, however, the well-established rule is that the employee has a duty to mitigate, so that wages he could have earned on a replacement job, but did not, will be offset against his recovery. ${ }^{124}$ This duty complements the rule that wages the employee actually does earn on a replacement job offset his recovery. Under the latter rule, an employee who takes a replacement job in effect works for the breaching employer rather than for himself. Unless a duty to take such a job existed, therefore, the offset rule might encourage employees to stand idle. ${ }^{125}$ For this reason, the same duty should apply to other sellers of services.

$226 \mathrm{~Pa}$. Super. at 224-25, 314 A.2d at 321-22. added).

123. Restatement (SECOND) OF CoNTRACTs $\$ 347$ comment f (1981)(emphasis

124. As has often been pointed out, use of the term "duty" in this context is questionable, since the employee does not incur liability if he fails to mitigate. See, e.g., McClelland v. Climax Hosiery Mills, 252 N.Y. 347, 358-59, 169 N.E. 605, 609 (1930)(Cardozo, J., concurring). However, the nomenclature is well-established and has not led to problems in the analysis.

125. Another justification of the duty to mitigate is that if the employee could have taken a replacement job but didn't, the employee's losses might be said to result from his own decision, rather than from the breach. Id. at 359, 169 N.E. at 609 (Cardozo, J., concurring). 
But what rule determines whether the duty to mitigate has been satisfied? The traditional statement of the duty frames the issue in objective and even standardized terms: The plaintiff has a duty to take a replacement job if it involves "similar employment, with similar conditions of employment and rank and in the same locality."126 However, a job that is objectively comparable, on an abstract level, to the job originally contracted for, may not satisfy the plaintiff for perfectly good reasons, ranging from quality of management to degree of risk. In such a case, a rule that in effect forces the plaintiff to take the replacement job violates the expectation principle because it places him in a worse position than he would have occupied had the defendant performed the original contract, which presumably involved a satisfactory job. A preferable approach, therefore, would be to treat an employee or other seller of services in the same manner as a covering buyer of goods, ${ }^{127}$ so that the search for a replacement is tested by a standard of reasonableness, but the substantive decision is tested by a standard of good faith. If the plaintiff failed to make a reasonable search, and if that search would have discovered an objectively comparable job, he should bear the uncertainty of whether he would have accepted the job. If he does make a reasonable search, however, he should not be constrained to accept an alternative job which he in good faith deems unsatisfactory. Like any subjective standard, this test is subject to abuse, but the likelihood of abuse seems small. Given normal economic and psychological needs, few persons are likely to turn down a satisfactory job in favor of inactivity and the chance of recovering damages that would put them in no better financial position than would the replacement job. ${ }^{128}$ As in the

126. D. DoBBs, supra note 58 , at 926 (footnotes omitted).

127. See notes 67-71 supra and accompanying text.

128. Cf. Few of the Poor Quilting Jobs to Get Back on Welfare Rolls, N.Y. Times, Oct. 25, 1982, at 1, col. 5:

Critics of President Reagan's budget cuts, including Democrats and welfare rights advocates, had said that under changes in the law enacted last year, poor people would often find it profitable to quit their jobs and depend entirely on welfare payments. Welfare recipients are automatically eligible for free or low-cost medical care under the Medicaid program, which they often lose when they leave the welfare rolls.

State officials said last week that the new law did contain "work disincentives," but that those cut off from welfare were trying to hold onto jobs or increase their earnings, even in a time of high unemployment.

"In purely economic terms, it did not make sense for some of these people to continue working," said Barbara Salisbury, budget director of the Massachusetts Department of Public Welfare. "But the people who were working want to work. They are not making decisions solely on the basis of what benefits them most in dollars and cents." 
case of cover, motives of self-regard will therefore indirectly control good faith, and in any event, good faith can be directly reviewed by the court.

The leading case of Parker v. Twentieth Century-Fox Film Corp. ${ }^{129}$ supports this bifurcated approach to search and decision. Shirley MacLaine had contracted with Fox to play the female lead in Bloomer Girl at a minimum compensation of $\$ 750,000$. Before production started, Fox decided not to produce the picture and offered MacLaine the lead in Big Country, Big Man for identical compensation. Big Country was to be filmed at the time scheduled for Bloomer Girl, but Bloomer Girl would have been a musical while Big Country would be a dramatic western, and Bloomer Girl would have been filmed in California while Big Country would be filmed in Australia. Also, the Bloomer Girl contract gave MacLaine the power of director and screenplay approval, but the Big Country contract provided only that Fox would consult with MacLaine on these issues. MacLaine rejected Big Country and brought suit for breach of contract. Fox pleaded that MacLaine, by refusing to accept Big Country, had failed to mitigate damages.

The California Supreme Court affirmed a summary judgment for MacLaine. The court made obeisance to the traditional statement of the mitigation rule by finding that the two roles were not equivalent, and that the changed contract provisions made Big Country "an offer of inferior employment."130 The thrust of the opinion, however, went considerably further. First, the court seemed to eviscerate the traditional, standardized test by indicating that any distinction between two jobs would render them different in kind as a matter of law. ${ }^{131}$ Second, the court properly drew a sharp distinction between search and decision:

129. 3 Cal. 3d 176, 474 P.2d 689, 89 Cal. Rptr. 737 (1970).

130. Id. at 184,474 P.2d at 694,89 Cal. Rptr. at 742 .

131. The mere circumstance that "Bloomer Girl" was to be a musical review calling upon plaintiff's talents as a dancer as well as an actress, and was to be produced in the City of Los Angeles, whereas "Big Country" was a straight dramatic role in a "Western Type" story taking place in an opal mine in Australia, demonstrates the difference in kind between the two employments . . . .

Id. at 183, 474 P.2d at 693-94, 89 Cal. Rptr. at 741- 42. As a dissenting opinion pointed out, Although the majority appear to hold that there was a difference "in kind" between the [two offers of employment], an examination of the opinion makes crystal clear that the majority merely point out differences between the two films (an obvious circumstance) and then apodically [sic] assert that these constitute a difference in the kind of employment.

Id. at 187, 474 P.2d at 696, 89 Cal. Rptr. at 744 (Sullivan, J., dissenting) (emphasis in original). 
In the present case defendant has raised no issue of reasonableness of efforts by plaintiff to obtain other employment . . . . Despite defendant's arguments to the contrary, no case . . . holds or suggests that reasonableness is an element of a wrongfully discharged employee's option to reject, or fail to seek, different or inferior employment ..... ${ }^{132}$

A footnote added, "Instead, in each case the reasonableness referred to [in the cases] was that of the efforts of the employee to obtain other employment that was not different or inferior; his right to reject the latter was declared as an unqualified rule of law."133

In summary, if a buyer of services breaches, the seller should recover under an individualized net-proceeds measure of damages. If the seller accepts a replacement job, his net proceeds on that job should offset his recovery against the buyer. The seller should make reasonable efforts to search for such a job, but his decision to reject a replacement job that he finds should be judged by the subjective standard of good faith.

\section{Breach by the service-provider.}

Suppose now that a contract for the provision of services is breached by the service-provider. As in a breach by a seller of goods, the expectation principle might appear to entitle the injured party to either specific performance or damages measured by the difference between the contract price and the value that he subjectively places on the services. However, specific performance will usually be either impracticable or unavailable for reasons of policy, ${ }^{134}$ and direct judicial measurement of the injured party's subjective value presents obvious problems of administration. Nevertheless, the courts usually can protect the injured party's actual expectation by applying an objective but individualized measure, based on the cost required to put the subject matter of the contract into its promised state-a measure generally known as cost of completion. At least where the injured party has actually had the work completed, cost of completion is analogous to cover. Like cover, cost of completion is both objective, since it does not depend on direct measurement of subjective valuation, and individualized, since it depends on the circumstances of the individual case. Moreover, cost of completion, like cover, should nor-

132. Id. at 182,474 P.2d at $692-93,89$ Cal. Rptr. at $740-41$ (emphasis in original; footnote omitted).

133. Id. at $182 \mathrm{n} .5,474 \mathrm{P} .2 \mathrm{~d}$ at $693 \mathrm{n} .5,89 \mathrm{Cal}$. Rptr. at $741 \mathrm{n} .5$ (emphasis in original).

134. See, e.g., London Bucket Co. v. Stewart, 314 Ky. 832, 834-35, 237 S.W.2d 509, 510 (1951). 
mally put the plaintiff in the same position as performance would have done. ${ }^{135}$

An alternative measure of damages for nonperformance of services is generally known as diminished value. Under this measure, the plaintiff recovers the difference between the market value of the contract's subject matter as it stands, and its market value had the seller performed as promised. Although this measure is essentially standardized, in a market with perfect information, cost-of-completion and diminished-value damages would usually be approximately equal, since the difference between the market value of the subject matter in its actual and promised states should usually equal the cost of transforming the subject matter from one state to the other. For example, with perfect information the difference between the value of a used television set with a broken tuner and the value of an otherwise identical working set should be the cost of repairing the broken tuner.

In certain circumstances, however, the two measures will differ. In some such cases, the courts have limited the recovery to diminished-value damages, over the injured party's objection. For example, in Peevyhouse v. Garland Coal $\mathcal{E}^{2}$ Mining Co. ${ }^{136}$ Peevyhouse leased farmland containing coal deposits to Garland for strip-mining, and Garland agreed to perform certain restorative work at the end of the lease. Garland left the restorative work undone and Peevyhouse sued for damages. Completion would have cost about $\$ 29,000$. In contrast, the total value of the restored land would have been less than $\$ 5,000$, and the difference between the market value of the land in its

135. As in the case of cover, the buyer's right to select substitute services must be subject to some limit. While that limit is often put in terms of an objective standard of reasonability, a subjective standard of good faith is preferable. For example, in R.K. Cooper Builders, Inc. v. Free-Lock Ceilings, Inc., 219 So. $2 d 87$ (Fla. Dist. Ct. App. 1969), Free-Lock breached a contract with Cooper under which Free-Lock was to install lighting fixtures. Cooper then paid Bernard Ceiling Company $\$ 5,681.34$ to perform the work remaining under the contract. The trial court found that "the reasonable amount of money required to complete the work was $\$ 2,500.00$." Id. at 88 . Cooper argued that "the issue is not . . . the reasonable value of the work and materials required to complete," and the Court of Appeal agreed:

Instead, controlling weight should be given to the actual expenditures, made in good faith, that are necessary to complete the job covered by the original contract. But we hasten to add that a mere showing of the actual expenses for completion is not determinative of the issue of damages, for the general rule permits the defaulting subcontractor to go forth with evidence in order to set off the cost of completion. Such evidence should go toward proving waste, extravagance, or lack of good faith, but the courts will not hear a defaulting subcontractor's claim that the party who was forced to complete the job spent too much absent evidence as to [those] factors. Id. at 88-89.

136. 382 P.2d 109 (Okla. 1962), cert. denied, 375 U.S. 906 (1963). 
restored and unrestored states was about $\$ 300$. The jury gave Peevyhouse a verdict for $\$ 5,000$, but the court held that Peevyhouse was limited to $\$ 300$ diminished-value damages. Similarly, in Eastern Steamship Lines, Inc. v. United States, ${ }^{137}$ the Government requisitioned Eastern's ship Acadia for use in World War II, and promised that before redelivery it would either restore the vessel to its condition at delivery or pay Eastern the amount reasonably expended to restore the vessel to that condition. Eastern brought suit for the projected cost of restoration, and the court assumed, for purposes of its opinion, that restoration would cost $\$ 4$ million and a restored Acadia would be worth $\$ 2$ million. The court concluded that Eastern's damages were limited to the value the Acadia would have if restored. ${ }^{138}$

Courts often give comparable treatment to a counterpart issue that arises when a contractor sues for payment even though he has not fully performed. For example, in Jacob $\mathcal{F}^{2}$ Youngs, Inc. v. Kent, ${ }^{139}$ Jacob \& Youngs contracted to build a country house for Kent. The contract specified that all wrought-iron plumbing pipe "must be . . . of the grade known as 'standard pipe' of Reading manufacture."140 After the house had been completed, and Kent had taken possession, he learned that the contractor had installed some pipe made by other manufacturers. The other brands were apparently equal in quality, appearance, market value, and cost to Reading pipe- "indeed, the same thing, though manufactured in another place."141 Since the plumbing was largely encased within the walls, installation of Reading pipe would have required the demolition of substantial parts of the house. The court held that Jacob \& Youngs was entitled to final payment under the contract, with a "measure of . . . allowance" equal to the difference in value. ${ }^{142}$

The principle that a court may limit the injured party to diminished-value damages is therefore well settled. However, the cases applying this principle have spelled out its rationale poorly at best, and the competing rules that have been advanced for imposing the limit are generally unsatisfactory. One rule, reflected in Section 346(1)(a)(i) of Restatement (First), is that the court should not award cost of completion if that measure would involve unreasonable eco-

137. 112 F. Supp. 167 (Ct. Cl. 1953).

138. Id. at 176.

139. 230 N.Y. 239 , 129 N.E. 889 (1921).

140. Id. at 240,129 N.E. at 890 .

141. Id. at 241,129 N.E. at 890 .

142. Id. at 244-45, 129 N.E. at $891-92$. 
nomic waste. ${ }^{143}$ An award of damages, however, merely redistributes wealth between the parties, and therefore cannot in itself involve waste. ${ }^{144}$ While a plaintiff may use the proceeds of a damage recovery to engage in activity the court would regard as wasteful, that has never been a criterion for selecting among damage measures. ${ }^{145}$

A second rule, reflected in Jacob $\mathcal{E}$ Youngs and Peevyhouse, is that courts should not award cost of completion if damages so measured would be "grossly and unfairly out of proportion" to the "result," "good," or "end" to be attained. ${ }^{146}$ The meaning of this rule is somewhat ambiguous. In some circumstances-Jacob $\mathcal{E}^{2}$ Youngs perhapsit might refer to a disparity between reward and risk. ${ }^{147}$ More often the rule seems to refer to a disparity between the cost of completion and the increased market value of the completed subject matter of

143. Restatement (FIRST) OF CONTRACTS $\$ 346(1)$ (a)(i) (1932); see also Hansen v. Andersen, 246 Iowa 1310, 1316, 71 N.W.2d 921, 924 (1955)(where changes necessary to comply with contract for construction of granary would involve unreasonable expense, proper measure of damages was difference between value of building as it would have been if constructed in compliance with agreement, and value "as is"); 5 A. CORBIN, supra note 52, § 1090 (1964)(economically wasteful remedies to be avoided with respect to construction contracts).

144. See Birmingham, Damage Measures and Economic Rationality: The Geometry of Contract Law, 1969 Duke L.J. 49, 69.

145. It is often said that cost-of-completion damages should not be awarded where completion would involve unreasonable destruction of completed work. See, e.g., Brewer v. Custom Builders Corp., 42 Ill. App. 3d 668, 674, 356 N.E.2d 565, 570 (1976); Wilson Concrete Co. v. A.S. Battiato Const. Co., 196 Neb. 185, 187, 241 N.W.2d 819, 820 (1976). The fact that expensive destruction of completed work would be required is some evidence that the owner would probably pocket a cost-of-completion recovery, rather than use it to have the work performed. However, if it seems probable that the owner values the contracted-for performance so highly that he would in fact destroy and reconstruct, he should be entitled to do so, and several cases have allowed cost-of-completion damages in such circumstances. See, e.g., Gory Associated Indus. Inc. v. Jupiter Roofing \& Sheet Metal, Inc., 358 So. 2d 93 (Fla. Dist. Ct. App. 1978)(cost of replacing roof made of a tile other than that specified in the contract); Edenfield v. Woodlawn Manor, Inc., 62 Ten. App. 280, 462 S.W.2d 237 (1970) (cost of replacing defective air-conditioning ducts, including cost of removing and restoring walls and cabinets to get at the ducts). In Gory the court said, "[W]e are sympathetic to a replacement of defective work. If a proud householder, who plans to live out his days in the home of his dreams, orders a new roof of red barrel tile and the roofer instead installs a purple one, money damages for the reduced value of his house may not be enough to offset the strident offense to aesthetic sensibilities, continuing over the life of the roof." 358 So. $2 \mathrm{~d}$ at 95.

146. Jacob \& Youngs, 230 N.Y. at 244, 129 N.E. at 891; accord Avery v. Fredericksen \& Westbrook, 67 Cal. App. 2d 334, 154 P.2d 41 (1944).

147. Cf. RESTATEMENT (SECOND) OF CONTRACTS § 351(3) (1981) ("A court may limit damages for foreseeable loss by excluding recovery for loss of profits, by allowing recovery only for loss incurred in reliance, or otherwise if it concludes that in the circumstances justice so requires in order to avoid disproportionate compensation."). Perhaps thinking along these lines, some courts have compared the cost of completion with the original contract price. See Walker Mfg. Co. v. Henkel Constr. Co., 346 F. Supp. 621 (N.D. Iowa 1972); J.G. Jansen, Inc. v. Rilling, 203 Wis. 193, 232 N.W. 887 (1930). 
the contract. Disparity between cost of completion and diminution in market value, however, should not in itself present a ground for refusing cost-of-completion damages. For example, assume that $A$ makes a contract with $B$ Painting Company under which $B$ agrees to paint $A$ 's house a particular shade of green for $\$ 3000$ while $A$ is on vacation. Through a mixup, $B$ 's employees paint $A$ 's house a shade of brown. $A$ hires another painter, who repaints the house the desired shade of green at a cost of $\$ 3200$. The repainting does not, however, increase the market value of the house, and in fact results in a decrease, since the green is particularly ugly while the brown was particularly beautiful. Here the cost of completion is immensely disproportionate to the diminished value, but it is hard to believe the courts would hold that $A$ could not recover that cost. ${ }^{148}$

A third rule, reflected in some of the commentary, is that the courts should not award cost of completion if that measure would create a windfall. This rule, however, provides no guidance for determining when a windfall would result. If completion is required to satisfy the plaintiff's expectation, it is hard to see why its cost would constitute a windfall. Indeed, limiting the plaintiff's damages to diminution in value may give the defendant a windfall. ${ }^{149}$

\section{Cf. Restatement (First) OF CoNTRACTS $§ 346$ illustration 4 (1932):}

4. $A$ contracts to construct a monumental fountain in $B$ 's yard for $\$ 5000$, but abandons the work after the foundation has been laid and $\$ 2800$ has been paid by $B$. The contemplated fountain is so ugly that it would decrease the number of possible buyers of the place. The cost of completing the fountain would be $\$ 4000$. $B$ can get judgment for $\$ 1800$, the cost of completion less the part of price unpaid.

Timothy Muris points out that performance must have a special value to the promisee if the contract price exceeds the expected augmentation of market value at the very time the contract is made (as it does in both illustration 4 and the green/brown paint hypothetical). Muris, Cost of Completion or Diminution in Market Value: The Relevance of Subjective Value, $12 \mathrm{~J}$. LEGAL STUD. 379, 384-85, 387 (1983).

149. Many other rules have also been proposed by the commentators. See, e.g., D. DOBBS, supra note 58, at 902 (where an owner is interested only in economic value to begin with, the difference between cost of completion and diminished value should be split between the parties); Farnsworth, Legal Remedies for Breach of Contract, 70 CoLum. L. REv. 1145, 1175 (1970) (where there is uncertainty concerning the difference between the value to the owner of the promised and the rendered performance, and cost of completion varies widely from diminished value, the trier of fact should have discretion to fix any figure, not unreasonable under the circumstances, so long as it lies within those two limits); Harris, Ogus \& Phillips, supra note 62, at 601-10 (courts should award the injured party the value he places on the promised performance); Marschall, Willfulness: A Crucial Factor in Choosing Remedies for Breach of Contract, 24 ARIz. L. REv. 733 (1982) (the choice between cost of completion and diminished value should turn on whether the breach was willful); Muris, supra note 148, at 395-96 (cost of completion should be awarded when (i) the original purchase price exceeds the fair market value at the time of purchase and the cost figure reflects the original cost of production; (ii) cost of completion is less than or equal to diminution in value; (iii) diminution in value is too difficult to calculate with reasonable certainty, or (iv) subjective value is relevant and cost of 
The underlying problem with all three rules is that they attempt to solve an essentially subjective problem with objective tests. The guiding rationale is very simple. The purpose of expectation damages is to put the injured party where he would have been had the contract been performed. Since cost-of-completion damages usually accomplish that objective, this measure should usually be utilized. It need not be utilized, however, where the factfinder is convinced it would not accomplish that objective because both the market and the plaintiff value the difference between the existing and promised states of the contract's subject matter at less than the cost of completion, and the plaintiff therefore would not use a recovery measured by that cost to achieve completion.

Several English cases have explicitly adopted this approach. For example, in Radford $v$. de Froberville ${ }^{150}$ Radford owned a house in London that was divided into flats and leased to residential tenants. The house had a large garden that included a plot of land suitable for building. In 1965 Radford sold the plot to de Froberville, who paid $£ 6,500$ and agreed she would immediately erect a brick wall separating the plot from the remainder of the garden and build a house according to specified plans. Eight years later, de Froberville had built neither the house nor the wall, and Radford sued for breach of contract, claiming as damages the $£ 3,400$ cost of building the wall on his side of the boundary. The lack of a wall did not significantly diminish the rental value of Radford's flats, and in fact, the adjoining open space may actually have enhanced the value of his property. The court nevertheless granted cost-of-completion damages, but only because it was persuaded that Radford actually did want the wall built:

[I]f that which is contracted for is not supplied by the other contracting party I do not see why, in principle, he should not be compensated by being provided with the cost of supplying it through

\footnotetext{
completion does not grossly exceed the likely subjective value); Yorio, In Defense of Money Damages for Breach of Contract, 82 Colum. L. REv. 1365, 1388-1423 (1982)(cost of completion should be awarded in all cases, unless the breach was inadvertant or due to changed circumstances; in those cases the innocent party should receive (i) half the difference between cost of completion and diminished value, (ii) half the gain that resulted to the contractor by virtue of the breach, or (iii) at least where the owner has derived no benefit, restitution of amounts paid to the contractor). Most of these rules turn in whole or in part on objective tests, or at least on an attempt to avoid determining subjective intent, and are therefore subject to the same problems as the rules advanced by the courts. Marschall's rule appears to turn on a subjective test - the willfulness of the breach - but as regards nonwillful breaches, Marschall suggests a balancing of the conventional objective factors, such as waste and disproportionality.
}

150. [1977] 1 W.L.R. 1262 (Ch.). 
someone else or in a different way, subject to the proviso, of course, that he is seeking compensation for a genuine loss and not merely using a technical breach to secure an uncovenanted profit. . . .

$\cdot \cdot \cdot$

... In applying [the principle that expectation damages should put the plaintiff where he would have been had the contract been performed], the court does not disregard the hopes and aspirations or the individual predilections of the particular plaintiff. . . .

$\cdots$.

... What the court does is to use its common sense in measuring, in the case of the individual plaintiff and by reference to his particular circumstances, what he has lost by the breach. ${ }^{151}$

151. Id. at 1270-72 (emphasis in original). The court continued:

Assume, for instance, two identical houses on an estate which have been let subject to a covenant for use as a single residence, each lease expiring at the same time, each containing a covenant against alteration. Each has been altered by the tenant, in breach of covenant, to form a number of flats and in each case the effect is to make the property more valuable as a marketable commodity. On the expiry of each lease, the landlord sues for damages. The landlord of one wishes to occupy it himself as a single residence for his family. The landlord of the other wishes to demolish it immediately for redevelopment. The adoption of a single universal principle which looks only at market value regardless of the wishes of the individual plaintiff would dictate a nominal award in both cases, but the authorities . . . show that the courts do not approach the problem in this way.

Id. at 1273 .

Similarly, in Tito v. Waddell (No.2), [1977] 1 Ch. 106 (Ch. 1976), the British Phosphate Commission had mined phosphate on Ocean Island plots prior to World War II, and was contractually obliged to restore and replant the mined-out plots to their original condition. In the aftermath of the Japanese occupation of Ocean Island during World War II, the surviving Islanders had been resettled on the Island of Rabi, 1600 miles away, and had voted overwhelmingly to make Rabi their home. As a result of the mining, the plots consisted of high coral pinnacles and a shallow layer of residual worked-out land, and restoration and replanting would have been extremely expensive. The transplanted Islanders sued for cost of completion, which was tacitly assumed to be significantly greater than the diminution in the land's value. The court limited the Islanders to diminution-in-value damages, but only because it concluded the Islanders did not actually intend to replant. The opinion made clear that a different result would have followed if the court had thought the Islanders really wanted restoration:

[S]ome contracts for alterations to buildings, or for their demolition, might not, if carried out, enhance the market value of the land, and sometimes would reduce it. The tastes and desires of the owner may be wholly out of step with the ideas of those who constitute the market; yet I cannot see why eccentricity of taste should debar him from obtaining substantial damages. . . .

$\cdots$

... [T] he plaintiff may establish that the cost of doing the work constitutes part or all of his loss in a variety of ways. . . .

. . . Suppose, then, that he has not done it but states that he intends to do it. Of course, he may not be believed: But if he is, why should not his loss be measured by what it will cost him to do the thing that the defendant ought to have done but did not do?

Id. at 332-33. 
The American cases, while not so explicit, also lend support to this approach. In Eastern Steamship Lines ${ }^{152}$ the court concluded, "Common sense and reality tell us" that if the plaintiff recovered $\$ 4$ million it would not spend that amount on restoration, "since after the expenditures it would have only a $\$ 2,000,000$ ship. The result would be that the Government would pay out $\$ 2,000,000$ more than the plaintiff had lost by the Government's chartering and use of its ship." 153 Similarly, in Peevyhouse ${ }^{154}$ the court said:

It should be noted that the rule as stated does not interfere with the property owner's right to "do what he will with his own". . . or his right, if he chooses, to contract for "improvements" which will actually have the effect of reducing his property's value. Where such result is in fact contemplated by the parties, and is a main or principal purpose of those contracting, it would seem that the measure of damages for breach would ordinarily be the cost of performance. ${ }^{155}$

And in Jacob $\mathcal{E}^{2}$ Youngs $^{156}$ the court said that its conclusion did not mean "that the parties are not free by apt and certain words to effectuate a purpose that performance of every term shall be a condition of recovery," but only that "the law will be slow to impute the purpose, in the silence of the parties, where the significance of the default is grievously out of proportion to the oppression of the forfeiture."157

While the ultimate issue is therefore subjective, the courts should normally determine that issue by looking to objective indicators, particularly whether the subject matter of the contract involved personal rather than strictly commercial interests, or whether strategic considerations, such as location, would lead the plaintiff to assign a value to the subject matter in its promised state higher than would the market. Thus in Edgar 0 . Hosea ${ }^{158}$ the court distinguished between com-

152. See notes 137-138 supra and accompanying text.

153. Eastem Steamship Lines, 112 F. Supp. at 175.

154. See note 136 supra and accompanying text.

155. Peevyhouse, 382 P.2d at 114. It is probably not accidental that many of the cases limiting the owner to diminution-in-value damages involve a failure to restore premises after mining or tenancy by the defendant, since in these cases it is often less clear that at the time of breach the owner's utility for restoration equals its cost. Indeed, some courts have said that, at least in restoration cases, diminished value is the normal measure, or that the plaintiff is entitled only to the lower of diminished value or cost of completion. See, e.g., Dodge Street Bldg. Corp. v. United States, 341 F.2d 641, 644 (Ct. Cl. 1965); Dimick v. Noonan, 242 S.W.2d 599 (Mo. App. 1951). The general rule, however, seems otherwise. See, e.g., P.G. Lake Inc. v. Sheffield, 438 S.W.2d 952 (Tex. Civ. App. 1969).

156. See notes 139-142 supra and accompanying text.

157. Jacob $\mathcal{F}$ Youngs, 230 N.Y. at $243-44,129$ N.E. at 891.

158. 210 So. $2 d 233$ (Fla. Dist. Ct. App. 1968). 
mercial and residential construction, and ruled that in cases involving the latter, damages should be measured by cost of completion, "since unlike a commercial structure, a dwelling has an esthetic value and must be constructed as the owner wants it, even though the finished dwelling may be just as good." 159 Applying these criteria to a case like Peevyhouse, the court should award cost-of-completion damages if the land was part of a family farm or was strategically located-if, say, it connected two other farmland plots owned by the plaintiff-while an agribusiness that owned no other nearby farms should recover only diminished-value damages. ${ }^{160}$

It might be argued that since the plaintiff has paid for completion, anything less than cost-of-completion damages would leave the defendant unjustly enriched. For example, assume that prior to its negotiations with Peevyhouse, Garland Coal had decided it was willing to pay royalties to Peevyhouse of one dollar per ton. When Peevyhouse demanded that Garland would have to restore the land, Garland would presumably have calculated the cost of restoration, prorated it over the expected tonnage, and agreed to pay Peevyhouse a royalty of a dollar per ton minus the prorated amount. On completion of the mining, Peevyhouse would then in effect have paid Garland an amount equal to the cost of restoration. Limiting damages to diminished value would confer a windfall on Garland equal to that cost. It can also be implied from this argument that instead of measuring damages by diminished value, the court should grant a decree of specific performance: If the plaintiff really wants completion, he will enforce the decree. If he does not, he will make a settlement that divides the windfall at some level between the amount at which he subjectively values the performance and the contractor's cost of completion. ${ }^{161}$

The problem with this argument and its implication is that in many cases the disparity between cost of completion and diminished market value results in large part from circumstances that were not anticipated when the contract was made. In Peevyhouse, for example,

159. Id. at 234 (quoting 13 AM. JUR. 2D Building and Construction Contracts $\$ 79$ (1964)) (emphasis omitted). See also Gory Associated Indus., Inc. v. Jupiter Roofing \& Sheet Metal, Inc., 358 So. 2d 93 (Fla. Dist. Ct. App. 1978) (discussed in note 145 supra).

160. In Peevyhouse itself, it seems likely that the land was part of a family farm, and the plaintiff sought to introduce evidence (which was excluded) that the land was part of a larger farm. On the apparent facts, therefore, the decision in Peevyhouse was wrong.

161. See D. DoBBS, supra note 58, at 902; Birmingham, supra note 144 , at $63-71$; Linzer, On the Amorality of Contract Remedies-Efficiency, Equity, and the Second Restatement, 81 CoLUM. L. REv. 111, 134-38 (1981). 
Garland's brief suggests that the restoration plan was based on the use of a spoil bank that was to be created by the mining operation. As matters turned out, however, Garland found much less coal than anticipated, the mine was not extended across the entire property, the planned spoil bank was not created, and restoration became much more expensive than originally contemplated. ${ }^{162}$ In Eastern Steamship Lines the court concluded that neither party had anticipated that by the end of the war the cost of labor would rise significantly while the value of used vessels would fall significantly. ${ }^{163}$ In Jacob $\mathcal{E}$ Youngs the parties obviously did not contemplate, at the time of contract formation, the cost of demolishing and reconstructing a completed structure. In such cases, the parties have not factored the cost of completion into the price paid by the plaintiff. Saving that cost would not, therefore, result in a windfall to the defendant, and if the plaintiff has no intent to complete, a decree of specific performance would enable the plaintiff to extract a windfall settlement.

Suppose, however, that the value the plaintiff assigns to the difference between the existing and promised states of the subject matter, although less than the cost of completion, is higher than the market-value differential. In principle, the plaintiff's recovery should be measured by this intermediate figure. ${ }^{164}$ (The jury in Peevyhouse may have done just that. ${ }^{165}$ ) Because such an approach would depend on a direct measurement of the plaintiff's subjective valuation, it would be open to criticism on administrative grounds. However, in many such cases there is a rough objective surrogate for the plaintiff's personal valuation of the difference: the amount the plaintiff effectively paid the defendant for completion, viewed ex ante at the time of contract formation. In Peevyhouse, for example, this amount would be the projected cost of restoration. In Jacob $\mathcal{E}^{2}$ Youngs it would be the projected difference between the cost of Reading and Cohoes pipe. This approach might itself present problems of administration, but in most cases the factfinder could probably make at least a rough estimate of the relevant amount. In Peevyhouse, one could compare the royalties offered to Peevyhouse with those offered to owners who did not require restoration; in Jacob $\mathcal{E}$ Youngs, one could compare the market prices of the pipe specified and the pipe installed, at the time

162. See L. Fuller \& M. Eisenberg, Basic Contract LAw 196-97 (4th ed. 1981)(citing to unpublished materials by Richard Danzig).

163. Eastern Steamship Lines, 112 F. Supp. at 175.

164. See Harris, Ogus \& Phillips, supra note 62, at 601-10.

165. I owe this observation to Tom Jackson. 
the contract was made. Indeed, where such an estimate is possible, the principle of unjust enrichment would independently support recovery on this basis. ${ }^{166}$ Furthermore, the defendant, at least, could hardly complain about the problem of administrability, because at worst he would pay no more, and probably much less, than the cost of a performance he admittedly agreed to complete.

In short, in cases where cost of completion substantially exceeds diminution in value, the analysis should proceed in three steps. First, if the plaintiff has actually paid a third party to have the work completed, damages should always be measured by cost of completion, since we know that cost of completion does not exceed the plaintiff's valuation of the differential between the existing and promised states of the subject matter of the contract. Second, if the plaintiff has not had the work completed, damages should be measured by cost of completion unless the defendant convincingly demonstrates that the plaintiff's valuation of the differential is significantly less than the cost of completion, and that the plaintiff therefore probably does not intend to complete. Third, if such a demonstration is made, damages should normally be measured by the greater of (i) diminution in value or (ii) the plaintiff's valuation of the differential, based, where possible, on the amount he paid for completion, viewed ex ante at the time of contract formation.

\section{CONCLUSION}

Until thirty or forty years ago, contract theory was dominated by the classical school. Central to the teachings of this school was a system of standardized and rigorously objective axioms that seem to have reflected implicit exemplary cases involving anonymous transactions in perfectly competitive markets. The axioms may have been workable in those cases, but they were too rigid to deal with cases involving the nuances of everyday life.

Because of the classical school's long dominance, even its critics came to accept that contract theory necessarily consisted of standardized and rigorously objective principles. However, close analysis shows that both contract theory and modern contract law can and

166. In Peevyhouse itself, the amount by which the defendant was unjustly enriched may have differed from the amount the plaintiff was willing to pay for completion, as of the time of contract formation. The amount the plaintiff was willing to pay is measured by the reduction in his royalties per ton by reason of the obligation to restore (as compared with marketbased royalties where there is no obligation to restore), multiplied by the projected tonnage. The amount by which the defendant was enriched is measured by the reduction in royalties per ton multiplied by the actual tonnage. 
should be conceptualized by a responsive model, in which the position of any given principle on the spectra running from standardization to individualization and from objectivity to subjectivity depends on a functional analysis of the relevant issue in terms of fairness and policy, so that principles are frequently individualized and sometimes subjective. This article has applied such a model to three critical areas of contract law-consideration, interpretation, and primary remedy rules.

A comparable analysis can be made in most other areas of contract law. For example, the law of performance has been heavily suffused with the doctrine of good faith, which is always individualized and sometimes subjective. ${ }^{167}$ The law of mistake has moved from an objective rule rejecting impalpable unilateral mistake as a defense to expectation damages, ${ }^{168}$ to a subjective rule that permits such a defense. ${ }^{169}$ The law of parol evidence is moving from a standardized rule-that a writing that appears complete supersedes all previous terms when "the alleged additional terms ordinarily and naturally would have been included in the writing by reasonable parties situated as were the parties to the writing"- to an individualized rule that "[a] writing is integrated when the parties intend it to be and it means what they intended it to mean."170

Similar developments have occurred in the area of secondary remedy rules. Courts now administer the rule of Hadley v. Baxendale $^{171}$ in a significantly more individualized manner than in the past. ${ }^{172}$ Case-by-case examination has replaced the relatively standardized application of the certainty doctrine, which provided a substantial barrier to the recovery of individualized consequential damages, particularly in the case of new businesses. ${ }^{173}$ An individualized rule now permits damages for injury to personal interests re-

167. See, e.g., U.C.C. $\$ \S 1-201(19), 1-203,2-103(1)$ (b) (1977); ResTatement (SECOND) of CONTRACTs § 205 (1981); Summers, "Good Faith" in General Contract Law and The Sales Provisions of the Uniform Commercial Code, 54 VA. L. REv. 195 (1968).

168. See, e.g., Steinmeyer v. Schroeppel, 226 Ill. 9, 80 N.E. 564 (1907); Restatement (FIRST) OF CONTRACTS $\S 503$ \& illustration 1 (1932).

169. See, e.g., Elsinore Union School Dist. v. Kastorff, 54 Cal. 2d 380, 353 P.2d 713, 6 Cal. Rptr. 1 (1960); RestaTEMENT (SECOND) OF CoNTRACTS $\$ 153$ \& comment c (1981).

170. Interform Co. v. Mitcheil Constr. Co., 575 F.2d 1270, 1275 (9th Cir. 1978).

171. 156 Eng. Rep. 145, 9 Ex. 341 (1854).

172. See, e.g., Mead v. Johnson Group, Inc., 615 S.W.2d 685 (Tex. 1981); RESTATEMENT (SECOND) OF CONTRACTS $§ 351$ comment a \& reporter's note to comment a (1981).

173. See, e.g., Rombola v. Cosindas, 351 Mass. 382, 220 N.E.2d 919 (1966); Fera v. Village Plaza, Inc., 396 Mich. 639, 242 N.W.2d 372 (1976); U.C.C. § 1-106 \& official comment 1 (1981); Restatement (SECOND) OF Contracts § 352 \& comment a (1981). 
sulting from breach of contract in cases where a standardized rule once prohibited such damages. ${ }^{174}$

The emerging doctrine of unconscionability is also producing a profound shift from standardized to individualized rules. For example, the standardized doctrine that the courts will not review the adequacy of consideration, which finds its primary justification in the exemplary case of transactions in a perfectly competitive market, may be giving way to the principle that in transactions under other market conditions the courts will police the unfair exploitation of distress, ignorance, or the like. ${ }^{175}$ Similarly, the standardized and objective rule that a party who signed a contract had a duty to read it, and was therefore bound by its provisions whether he knew them or not, ${ }^{176}$ is giving way to the individualized and subjective rule that a party is not bound by an unfairly surprising provision unless he had actual knowledge of it. ${ }^{177}$

In short, standardized principles are almost everywhere giving way to individualized principles, and contract theory no longer dismisses the significance of subjective elements. While further development of the responsive model of contract law is still necessary, even now it seems fair to say that in modern times, contract theory has evolved away from the rigidities of the classical model, into a supple instrument consisting of principles that are intellectually coherent but also responsive to intentions and circumstances.

174. See, e.g., Mieske v. Bartell Drug Co., 92 Wash. 2d 40, 593 P.2d 1308 (1979); Jarvis v. Swans Tours Ltd., [1973] 1 Q.B. 233 (C.A.).

175. See Eisenberg, The Bargain Principle and Its Limils, supra note 12, at 743-85.

176. See, e.g., Sardo v. Fidelity \& Deposit Co., 100 N.J. Eq. 332, 134 A. 774 (1926).

177. See, e.g., Weaver v. American Oil Co., 257 Ind. 458, 276 N.E.2d 144 (1971); Johnson v. United Investors Life Ins. Co., 263 N.W.2d 770 (Iowa 1978); Gerhardt v. Continental Ins. Cos., 48 N.J. 291, 225 A.2d 328 (1966); Restatement (SECOND) OF CoNTRACTs § 211 (1981). In Weaver, the court said:

When . . the contract, which is sought to be enforced, was in fact an unconscionable one, due to a prodigious amount of bargaining power on behalf of the stronger party, which is used to the stronger party's advantage and is unknown to the lesser party, causing a great hardship and risk on the lesser party . . . . [t]he party seeking to enforce such a contract has the burden of showing that the provisions were explained to the other party and came to his knowledge and there was in fact $a$ real and coluntary meeting of the minds and not merely an objective meeting. . . . We do not mean to say or infer that parties may not make contracts exculpating one of his negligence and providing indemnification, but it must be done knowingly and willingly. . . . 257 Ind. at 464-65, 276 N.E.2d at 148 (emphasis in original). 
